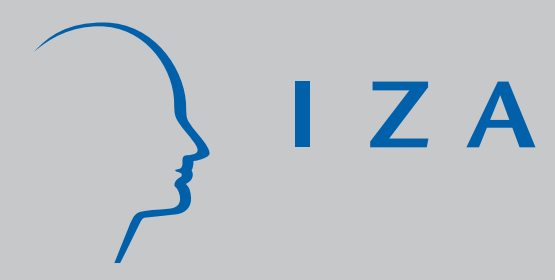

IZA DP No. 1419

Language Skills and Immigrant Adjustment: What Immigration Policy Can Do!

Barry R. Chiswick

Paul W. Miller

November 2004 


\title{
Language Skills and Immigrant Adjustment: What Immigration Policy Can Do!
}

\author{
Barry R. Chiswick \\ University of Illinois at Chicago \\ and IZA Bonn \\ Paul W. Miller \\ University of Western Australia \\ and IZA Bonn
}

\section{Discussion Paper No. 1419 \\ November 2004}

\author{
IZA \\ P.O. Box 7240 \\ 53072 Bonn \\ Germany \\ Phone: +49-228-3894-0 \\ Fax: +49-228-3894-180 \\ Email: iza@iza.org
}

\begin{abstract}
Any opinions expressed here are those of the author(s) and not those of the institute. Research disseminated by IZA may include views on policy, but the institute itself takes no institutional policy positions.
\end{abstract}

The Institute for the Study of Labor (IZA) in Bonn is a local and virtual international research center and a place of communication between science, politics and business. IZA is an independent nonprofit company supported by Deutsche Post World Net. The center is associated with the University of Bonn and offers a stimulating research environment through its research networks, research support, and visitors and doctoral programs. IZA engages in (i) original and internationally competitive research in all fields of labor economics, (ii) development of policy concepts, and (iii) dissemination of research results and concepts to the interested public.

IZA Discussion Papers often represent preliminary work and are circulated to encourage discussion. Citation of such a paper should account for its provisional character. A revised version may be available directly from the author. 


\section{ABSTRACT \\ Language Skills and Immigrant Adjustment: What Immigration Policy Can Do! ${ }^{*}$}

This study provides an account of the dynamics of the dominant language adjustment process among immigrants in Australia using the Longitudinal Survey of Immigrants to Australia, which comprises two cohorts of immigrants that arrived in Australia around five years apart. There are two special features of these data that provide the framework for analysis. First, the visa class under which the immigrants entered Australia is known from administrative records. Second, between the two surveys, some visa classes, but not others, were affected by changes in government policy relating to the role of English language skills in immigrant selection. A difference between differences approach is used to isolate the impacts of these policy changes, and thus enable an assessment of what immigrant selection policy can do in this area. It is found that visa category, educational attainment and age at migration impact on immigrant's language skills. The increased English Proficiency requirement for the Independent and Skilled-Australian Sponsored categories appears to have been successful in raising the English language proficiency of these immigrants.

JEL Classification: F22, J61, J15, J24

Keywords: immigrants, immigration policy, language, visa category

Corresponding author:

Barry R. Chiswick

Department of Economics (M/C 144)

University of Illinois at Chicago

601 South Morgan Street (2103 UH)

Chicago, IL 60607-7121

USA

Email: brchis@uic.edu

\footnotetext{
* Financial assistance from the Australian Research Council is acknowledged. The authors wish to thank Alice Summers and David Osborne for provision of background information on Australia's immigration policy and the Longitudinal Survey of Immigrants to Australia, Sue Fong Kong for data provision, Derby Voon for research assistance, and the many individuals who have commented on our research into language skills over the past decade.
} 


\section{LANGUAGE SKILLS AND IMMIGRANT ADJUSTMENT: WHAT IMMIGRATION POLICY CAN DO!}

\section{Introduction}

Knowing the reasons for the language skills of immigrants is important for understanding the determinants of their economic well-being, as well as other aspects of their economic, political, and social life in the destination. Adult immigrant language skills are also of interest because these influence the language skills and other dimensions of human capital formation of their children. Accordingly, the identification of the groups "at risk" of lacking proficiency in an official language can provide a basis for the design of more effective public policies regarding immigration, language training, and the labor market. Moreover, the changes in immigrants' language skills with duration in the destination country can inform on economic adjustment and cultural assimilation.

Much of our knowledge in this area has been taken from cross-sectional surveys. Study of such data suggests that immigrants rapidly acquire proficiency in destination language skills with length of time in the destination (see, for example, Chiswick and Miller (1995)). However, longitudinal inferences, such as on immigrants' development of dominant language skills, generally should not be made on the basis of cross-sectional evidence, which rests on comparisons of groups of immigrants that arrived in a country in different time periods. Where possible, longitudinal data should be used for this purpose, if only to test the robustness of cross-sectional estimates.

This study provides an account of the dynamics of the dominant language adjustment process among immigrants in Australia. It is based on longitudinal surveys of two cohorts of immigrants that arrived in Australia around five years apart. There are two special features of these data that provide the framework for the analysis. The first is that the visa class under which the immigrants entered Australia is known. There are five major visa groups ${ }^{1}$ : Independent; Skilled-Australian Sponsored; Business Skills and Employer Nomination Schemes; Family; and Humanitarian. Both the Independent and

\footnotetext{
1 The names of the visa groups have changed over time. For example, the SkilledAustralian Sponsored group was formerly termed the Skilled-Australian Linked category, and before that the Concessional Family category. The names in place in the late 1990s are used in this study.
} 
Skilled-Australian Sponsored immigrants are points tested for entry into Australia, with the main difference between the categories being that the Skilled-Australian Sponsored immigrants need to be sponsored by an Australian citizen, and additional points are available for aspects of this sponsorship. Sponsorship by an Australian plays no role in the Independent visa category. Under points testing, points are awarded for a range of attributes that are held to be important to immigrants' employment prospects and settlement in Australia, and only those immigrants with more points than the administratively determined threshold are eligible to be granted a visa. One of the attributes that is awarded points is English language ability.

As a result of a Review (1999) by the Department of Immigration and Multicultural Affairs in the late 1990s, changes were made to the points test which strengthened the role of English language ability in the selection for entry into Australia of immigrants in the Independent and Skilled-Australian Sponsored categories.

This provides the second special feature of the data. Many of those in the second cohort in the Independent and Skilled-Australian Sponsored categories were points tested under a policy that gave greater emphasis to English language ability than was the case for the first cohort. ${ }^{2}$ Immigrants in the two cohorts in the Family, Business Skills and Employer Nomination Schemes, and Humanitarian categories were not affected by this change in policy. ${ }^{3}$ Comparisons between cohorts within the Family, Business Skills and Employer Nomination Schemes and Humanitarian visa groups therefore provide information on cohort effects, such as those that might arise from general changes in the Australian economy or in the international market for immigrants that might lead one cohort of immigrants to be more skilled or less skilled than another. Comparisons between the two cohorts of immigrants with Independent and Skilled-Australian Sponsored visas will provide information on the effects of both cohort differences and

\footnotetext{
2 The spouses of Principal Applicants in the points tested categories may have been indirectly affected by this policy change, as points were now awarded when the spouse met certain core requirements (see below).

3 Potential immigrants can be viewed as seeking the "cheapest/easiest" visa they can obtain. In the Skilled-Australian Sponsored group, this is formally recognized in the processing of applications, with the points for spouses being compared and the higher score used.
} 
policy changes regarding English language proficiency. Finally, comparisons of the changes observed for the groups of immigrants points tested and not points tested for entry into Australia will, assuming that the cohort changes, if any, are the same for both groups of immigrants, enable the impacts of the policy changes to be isolated, and thus permit an assessment of what immigration policy can do in this area.

The structure of this paper is as follows. Section II describes the data sets used in the study. It also outlines the points test used for selecting immigrants for entry into Australia. Section III provides a descriptive overview of the language ability of the two cohorts of immigrants at several points in time. It covers reading and writing skills as well as the speaking skills that have been the focus of most analyses to date. Section IV presents statistical analyses of immigrants' English ability. These analyses are based on both Principal Applicants and on Migrating Unit Spouses. The Principal Applicant is the person upon whom the approval to immigrate was based, and Migrating Unit Spouses are spouses who were part of the application to migrate made by the Principal Applicants. Section V contains a summary and conclusion.

\section{The LSIA Data and Points Tests in Australian Immigration}

The analyses reported below are based on the Longitudinal Survey of Immigrants to Australia (LSIA), a set of two longitudinal surveys of immigrants who received their visas before entry into Australia. The two surveys are termed LSIA-Cohort 1 and LSIACohort 2, and are referred to as LSIA1 and LSIA2 in this study. The population represented in the first sample (LSIA1) is all Principal Applicants, aged 15 years and over, who arrived in Australia as offshore visaed immigrants in the two-year period of September 1993 to August $1995 .^{4}$ The population represented in the second sample

\footnotetext{
${ }^{4}$ Excluded from the scope of the survey are New Zealand citizens for whom there is unrestricted entry into Australia and those granted a visa while resident in Australia. In 1993-1994, approximately 14,000 persons were granted on-shore resident status, compared with around 70,000 settler arrivals. In 1999-2000, the number of persons granted on-shore resident status was slightly more than 17,500, compared to over 90,000 settler arrivals. The number of persons granted on-shore resident status jumped in 19941996 (as a consequence of the Tiananmen Square massacre), and has increased to around 30,000 in recent years. However, for the particular cohorts followed, the two longitudinal surveys cover similar proportions of all immigrants.
} 
(LSIA2) is all Principal Applicants, aged 15 years and over, who arrived in Australia under similar circumstances between September 1999 and August 2000. ${ }^{5}$ Weights are available in the sample file, and these are used so that all analyses represent the population of arrivals, as determined from immigration arrivals data.

Immigrants were interviewed three times in LSIA1. The first interview took place approximately five or six months after arrival, the second interview one year later (1995-1996) and the third interview a further two years later (1997-1998), or 3.5 years after immigration. However, only two sets of interviews were conducted for LSIA2: after six months of residence in Australia, and one year later.

The final LSIA1 sample was 5192 Principal Applicant arrivals. In addition, the spouses of 1837 of these Principal Applicants, known as Migrating Unit Spouses (MUS), were also interviewed. The LSIA2 sample initially comprised 3124 Principal Applicants and 1094 Migrating Unit Spouses. For each cohort, the population from which the sample was selected was stratified according to visa eligibility category. As noted above, there are five broad visa categories: Independent; Skilled-Australian Sponsored; Business Skills and Employer Nomination Schemes; Family; and Humanitarian. The first two of these are points tested to determine the eligibility of the applicants.

Points testing in skilled migration categories in Australia was introduced in $1989 .{ }^{6}$ The major aim of this type of selection mechanism is to identify factors in a potential migrant that will benefit Australia or assist with the settlement process, and the factors that enter into the points test are largely those which have been identified in applied labor market research as being associated with more rapid adjustment among immigrants (e.g., education attainment, labor market experience, English language proficiency, age). The main changes to the points test over the first few years of operation were to the list of occupations included in the Priority Occupation List (a list of occupations where there

${ }^{5}$ The two cohorts entered Australia at different stages of the business cycle. The adult male unemployment rate was 11.3 percent in August 1993, 9.4 percent in 1994 and 8.6 percent in 1995. In 1999 this rate was 7.0 percent, and it was 6.4 percent in 2000.

${ }^{6}$ See Kan (1991), Appendix 1, for information on changes in Australia's immigration policy leading up to 1989. As noted by Kan, numerical scoring was used as an administrative arrangement as early as 1979 . The importance of the change in 1989 was that the points system was recognized in law. 
may be job opportunities in Australia, and hence which attracted additional points) ${ }^{7}$ and the list of Occupations Requiring English. A Principal Applicant whose occupation was on the list of Occupations Requiring English was required to speak and write English fluently as well as pass the points test. ${ }^{8}$ The components of the points tests at August 1993, which were relevant for many in the LSIA1, are presented in Table $1 .{ }^{9}$

In 1993, to pass the test, Independent applicants needed to achieve 110 points. The Skilled-Australian Sponsored category (which has points for family links) had a pass mark of 100. A second threshold that is important is the "pool" mark. ${ }^{10}$ In 1993 this was 10 points lower than the pass mark for both the Independent category and the SkilledAustralian Sponsored category. Applications that did not reach the pool mark were refused outright. Applications which did not meet the pass mark but which achieved the pool mark were held in reserve in case a lower pass mark is set. ${ }^{11}$

Applications which pass the points test for the Independent and Skilled-Australian Sponsored categories but which would result in the yearly immigration planning limit being exceeded are processed up to visa stage. Visas are not issued, however, until a place becomes available in the program in subsequent years. This is termed "cap and queue".

\footnotetext{
${ }^{7}$ From October 1992 there were no occupations on the Priority Occupation List. The principle of targeting particular occupations was, however, re-introduced in the more recent post July 11999 points test.

${ }^{8}$ At this time, occupation was defined as the usual occupation, namely the job in which the applicant had worked continuously for at least six months in the two years prior to lodging their application.

${ }^{9}$ When a visa is issued to a Principle Applicant visas are also generally issued to the applicant's spouse and all minor or dependent children.

${ }^{10}$ In 1993 there was also a "Priority Mark". As this had been set equal to the Pass Mark from 1990, and was abandoned in 1994, it is not included in this discussion.

${ }^{11}$ Initially the applications in the pool were held until they were assessed against three different pass marks. Since 1994 pooled applications were held for one year only.
} 


\section{Table 1}

\section{Characteristics Awarded Points and Points Available, Skilled Migration in Australia: August 1993}

\begin{tabular}{|c|c|}
\hline Characteristics & Points as at August 1993\# \\
\hline $\begin{array}{l}\text { Skills: } \\
\text { Occupation }\end{array}$ & $\begin{array}{l}10 \text { points for occupations that required } 10 \text { years of primary and secondary } \\
\text { schooling; } \\
20 \text { points for occupations requiring } 12 \text { years of primary and secondary } \\
\text { schooling; } \\
25 \text { points for other post-school qualifications or unrecognized post- } \\
\text { secondary qualifications; } \\
30 \text { points for post-secondary qualifications that need only minor upgrading, } \\
\text { with at least } 3 \text { years post-qualification work experience; } \\
50 \text { points for acceptable diploma with } 6 \text { months to } 3 \text { years post- } \\
\text { qualification work experience; } \\
55 \text { points for diploma with at least } 3 \text { years post-qualification work } \\
\text { experience; } \\
60 \text { points for trade certificate/degree with } 6 \text { months to } 3 \text { years post- } \\
\text { qualification work experience; } \\
70 \text { points for trade certificate/degree with at least } 3 \text { years post-qualification } \\
\text { work experience; } \\
80 \text { points for trade certificate/degree/diploma with at least } 3 \text { years post- } \\
\text { qualification work experience and included on Priority Occupation list. }\end{array}$ \\
\hline Age: & $\begin{array}{l}18-29 \text { years: } 30 \text { points } \\
30-34 \text { years: } 20 \text { points } \\
\text { 35-39 years: } 10 \text { points } \\
\text { 40-49 years: } 5 \text { points }\end{array}$ \\
\hline English Language $\dagger$ & $\begin{array}{l}5 \text { points if able to handle basic communication in English on familiar } \\
\text { everyday topics or bilingual in languages other than English; } \\
10 \text { points if reasonably proficient in English but some training required; } \\
20 \text { points if proficient in English (able to speak and write English well). }\end{array}$ \\
\hline Relationship Factor* & $\begin{array}{l}15 \text { points if applicant was the parent, brother, sister, non-dependent child, } \\
\text { nephew or niece of sponsor. }\end{array}$ \\
\hline Citizenship Factor* & $\begin{array}{l}5 \text { points if sponsor had been an Australian citizen for fewer than } 5 \text { years; } \\
10 \text { points if sponsor had been an Australian citizen for } 5 \text { years or more. }\end{array}$ \\
\hline Settlement Factor* & $\begin{array}{l}10 \text { points if sponsor has been resident in Australia for } 2 \text { years and in } \\
\text { continuous employment in Australia for the last two years. }\end{array}$ \\
\hline Location Factor* & $\begin{array}{l}5 \text { points if sponsor has lived in one of a number of special designated areas } \\
\text { for the last two years. }\end{array}$ \\
\hline \multicolumn{2}{|c|}{$\begin{array}{l}\text { Note: \# General requirements related to age (the applicant needed to be less than } 65 \text { years if male, less than } \\
60 \text { years if female) and language (proficient in English if the applicant's occupation was listed in } \\
\text { the Occupations Requiring English list). } \\
\text { † Applies to Independent immigrants only. } \\
\text { * Applies to Skilled-Australian Sponsored immigrants only. } \\
\text { Source: Department of Immigration and Ethnic Affairs, Form 958i. August } 1993\end{array}$} \\
\hline
\end{tabular}


Since August 1993, there have been various changes to the points tests. These were of a relatively minor nature until July 1, 1999, when the recommendations of a major review (see Review of the Points Test for the Independent and Skilled Australian Linked Visa Categories (1999)) of the points test were implemented.

The minor changes to the points test over 1993 to 1999 include a number that relate to English skills. First, the points available for various levels of English ability were altered on May 23, 1994 (with a 15-point category being inserted between existing 10- and 20-points categories). ${ }^{12}$ Second, points were introduced for English language ability for immigrants in the Skilled-Australian Sponsored category on July 1, 1997. Third, there was expansion in the number of occupations included on the list of Occupations Requiring English, so that by 1998 this covered almost all skilled occupations. Fully 85 percent of points-tested applicants needed to meet his requirement. ${ }^{13}$ Fourth, in 1996 there was a change in the English requirements for these occupations to "vocational English", defined as the ability to communicate effectively in English in at least three of the four skills of reading, speaking, understanding and writing. In other words, applicants needed to be eligible for at least 15 points for English skills to meet this threshold. Fifth, from 1997, where skilled applicants (or their family members aged 18 or over) lacked functional English, applicants were required to pay for appropriate English language training. In total, these changes increased the English language requirements for entry into Australia.

The recommendations of the major review of the points test in the late 1990s (see Review of the Points Test for the Independent and Skilled Australian Linked Visa Categories (1999)) were implemented from July 1, 1999. From this date the points were as outlined in Table 2 .

\footnotetext{
${ }^{12}$ The points awarded were as follows: "Able to communicate effectively in English in a range of situations"-20; "At the level described for 20 points for three of the four skills of reading, speaking, understanding and writing, but at a lower level for the remaining skill"-15 points; "Able to communicate effectively in English on familiar, everyday topics" -10 points; "Able to handle basic communication in English on familiar everyday topics or fluent in at least two languages other than English" -5 points.

${ }^{13}$ Review of the Points Test for the Independent and Skilled Australian Linked Visa Categories (1999, p. 50).
} 
Table 2

\section{Characteristics Awarded Points and Points Available, Skilled Migration in Australia: July 1, 1999}

\begin{tabular}{|c|c|}
\hline Characteristics & Points from 1 July 1999\# \\
\hline $\begin{array}{l}\text { Skills: } \\
\text { Occupation }\end{array}$ & $\begin{array}{l}40 \text { points for occupations that require diploma or advanced diploma level } \\
\text { qualifications; } \\
50 \text { points for 'generalist' occupations which require degree level training; } \\
60 \text { points for occupations that require degree (or higher) qualifications and } \\
\text { where training specific to the occupation is necessary. }\end{array}$ \\
\hline $\begin{array}{l}\text { Skills: } \\
\text { Experience }\end{array}$ & $\begin{array}{l}5 \text { points for applications who have been employed in a skilled occupation } \\
\text { for } 3 \text { of the } 4 \text { years before applying; } \\
10 \text { points for applicants who have worked in a high-skilled occupation for } 3 \\
\text { of the } 4 \text { years before applying. }\end{array}$ \\
\hline Age & $\begin{array}{l}18-29 \text { years: } 30 \text { points } \\
\text { 30-34 years: } 25 \text { points } \\
\text { 35-39 years: } 20 \text { points } \\
\text { 40-44 years: } 15 \text { points } \\
\text { 45+ years: Ineligible for a visa }\end{array}$ \\
\hline English Language & $\begin{array}{l}15 \text { points for vocational English } \\
20 \text { points for competent English }\end{array}$ \\
\hline Occupational Targeting & $\begin{array}{l}5 \text { points for skills in short supply in Australia } \\
5 \text { further points for a job offer in a high-demand occupation }\end{array}$ \\
\hline Spouse Skills & 5 points where the spouse meets the core requirements \\
\hline Australian Qualifications & $\begin{array}{l}5 \text { points for a diploma, trade qualification or degree from an Australian } \\
\text { institution } \\
10 \text { points for a higher degree from an Australian institution }\end{array}$ \\
\hline Bonus Points & $\begin{array}{l}5 \text { points for one of: } \\
\text { - } 6 \text { months Australian work experience in a skilled occupation in the past } \\
4 \text { years; } \\
\text { - commitment to bringing a high level of capital to Australia; } \\
\text { - a high level of fluency on one of Australia's major non-English } \\
\text { community languages. }\end{array}$ \\
\hline Sponsorship* & 15 points \\
\hline Settlement/Location & Relaxation of pass mark \\
\hline $\begin{aligned} \text { Note: \# } & \text { General requirem } \\
& \text { employment in o } \\
& \text { months, dependir } \\
& \text { their application, } \\
* & \text { Skilled-Australia }\end{aligned}$ & $\begin{array}{l}\text { known as core criteria, were a requirement to meet Australian standards for } \\
\text { a range of occupations, have recent work experience (of between } 12 \text { and } 24 \\
\text { the occupation nominated), be younger than } 45 \text { years at the time of lodging } \\
\text { be proficient in English at the vocational level. } \\
\text { onsored only. }\end{array}$ \\
\hline
\end{tabular}


In 1999, to pass the test, Independent applicants needed to achieve 110 points. The Skilled-Australian Sponsored category also had a pass mark of 110. The "pool" marks for these categories in 1999 were 70 and 110 respectively.

In addition to the points test, applicants in the skilled migration categories (Independent and Skilled-Australian Sponsored) are now required to meet Australian standards for employment in one of a range of occupations, have recent work experience (of between 12 and 24 months, depending on the occupation nominated ${ }^{14}$ ), be younger than 45 years at the time of lodging their application, and be proficient in English at the vocational level. These minimum thresholds are termed core criteria, and represent a tightening of the former equivalent requirements which related to English proficiency in the Occupations Requiring English.

About 35 percent of the Independent visaed immigrants and 20 percent of the Skilled-Australian Sponsored immigrants in the second cohort of the LSIA entered on visas assessed under the post July 1, 1999 points test. ${ }^{15}$ The remainder and those in the first cohort of the LSIA, entered on visas assessed under different points tests.

Comparison of the points tests that were in operation in 1999 and 1993 highlights four major differences.

First, minimum standards were not explicitly specified in relation to the skills, age and English language ability of either Independent or Skilled-Australian Sponsored immigrants prior to July 1, 1999. Hence, skilled immigrants in the second cohort of the LSIA assessed under the post July 1, 1999 points test are expected to have at least vocational English, where this is prescribed in terms of a minimum score of at least five for all four components (writing, reading, listening and speaking) on the International

\footnotetext{
${ }^{14}$ Under the new points test, applicants were required to nominate the occupation against which they wish to be assessed, and for which they meet Australian standards. This does not have to be their "usual" occupation, as defined above.

${ }^{15}$ Immigrants in the newer visa classes were over-sampled. The respective population estimates are 17 percent of Independent immigrants and 4 percent of Skilled-Australian Sponsored immigrants, respectively.
} 
English Language Testing System ${ }^{16,17}$. There was, however, no such minimum threshold in place for all immigrants in the first cohort or for those in the second cohort assessed under the pre July 1, 1999 points test. ${ }^{18}$ The impact of this policy change will be moderated, however, by the fact that immigrants assessed under the pre July 1, 1999 points tests were required to possess vocational English if their usual occupation was on the Occupations Requiring English list, and, as noted above, this list had been expanded over time so that by 1998 it included around 85 percent of all points-tested applicants needed to meet this requirement.

Second, until July 1, 1997, points were not available for English language ability for immigrants in the Skilled-Australian Sponsored category (Department of Immigration and Multicultural Affairs 1999, p. 50). Skilled-Australian Sponsored immigrants in the second cohort of the LSIA are therefore expected to have initial English language skills superior to those of their counterparts in the first cohort of the LSIA. Given the presence of such points for Independent immigrants in LSIA1, the move to the common requirement for English language ability for skilled immigrants should be associated with far more pronounced changes in initial English language skills for Skilled-Australian Sponsored visaed immigrants than for Independent class immigrants.

Third, the other, seemingly more minor, changes to the role of English language ability in immigrant selection in Australia will impact positively on those in LSIA2, and hence reinforce the effects of the more pronounced policy changes noted above. These

\footnotetext{
${ }^{16}$ The International English Language Testing system is jointly managed by University of Cambridge ESOL Examinations, the British Council and IDP Education Australia: IELTS Australia. Further details are available from http://www.ielts.org/what.htm.

${ }^{17}$ According to the IELTS website, a score of 5 indicates that the individual has partial command of the language, coping with overall meaning in most situations, though he is likely to make many mistakes. The individual should be able to handle basic communication in his own field. As a benchmark, an overall score of 6.0 on this test will satisfy immigration requirements (though not necessary those of individual institutions) for a student visa for enrolment in a higher education degree in Australia.

18 The importance of this has been noted by the Department of Immigration and Multicultural Affairs 1999, p.36), "Under the current pass mark...(Skilled-Australian Sponsored applicants) may gain sufficient points ...if their occupation is not on the Occupations Requiring English list, where they speak no English".
} 
include, for example, changes in the points available for various levels of English ability on May 231994 when a 15-point category was inserted between the existing 10- and 20points categories.

Fourth, prior to July 1, 1999, the modest (five) number of points currently allocated when the applicant's spouse also meets the core criteria for skills were not available. This may have a small positive impact on the language skills of the spouses of principal applicants and a negative impact on the Principal Applicant's proficiency at the time of application.

The availability of the two cohorts of data with some immigrants (Family, Business/Employer Nomination Scheme, Humanitarian) not affected by the policy changes in relation to English skills, and with other immigrants directly affected by these policy changes to varying degrees, provides a natural experiment of what governments can do in relation to immigrants' initial language skills. Moreover, with the second cohort, there are sufficient Independent visaed immigrants who entered under either the pre- or post-July 1 regulations (where the major change is the introduction of the core criteria) to permit assessment of the impact of this change within a cohort. Table 3 displays the main comparisons possible with these data. While the threshold, or pass, number of points changed over 1993-1999 ${ }^{19}$, as the characteristics that could be awarded points also changed, it is unclear if these changes in the pass marks represented a tightening or weakening of quality controls.

\footnotetext{
${ }^{19}$ See the Review of the Points Test for the Independent and Skilled Australian Linked Visa Categories (1999), Attachment A, reproduced in part in Appendix A.
} 
Table 3

Role of English Language Ability in Immigrant Selection in LSIA1 and LSIA2

\begin{tabular}{|l|l|l|l|}
\hline Visa Category & LSIA1 & LSIA2 - Pre July 1 1999 & $\begin{array}{l}\text { Main Differences between } \\
\text { Cohorts }\end{array}$ \\
\hline $\begin{array}{l}\text { Non points tested } \\
\text { Humanity, }\end{array}$ & $\begin{array}{l}\text { No points for English } \\
\text { ability; no minimum } \\
\text { English threshold. }\end{array}$ & $\begin{array}{l}\text { No points for English } \\
\text { ability; no minimum } \\
\text { English threshold. }\end{array}$ & Cohort effects \\
\hline Independent & $\begin{array}{l}\text { Points for English } \\
\text { ability; English fluency } \\
\text { required if usual } \\
\text { occupation on ORE list; } \\
\text { no minimum English } \\
\text { threshold. }\end{array}$ & $\begin{array}{l}\text { Points for English ability; } \\
\text { English fluency required } \\
\text { if usual occupation on } \\
\text { ORE list; no minimum } \\
\text { English threshold. }\end{array}$ & $\begin{array}{l}\text { Impact of changes in ORE } \\
\text { list + cohort effects }\end{array}$ \\
\hline $\begin{array}{l}\text { Skilled-Australian } \\
\text { Sponsored }\end{array}$ & $\begin{array}{l}\text { No points for English } \\
\text { ability; English fluency } \\
\text { required if usual } \\
\text { occupation on ORE list; } \\
\text { no minimum English } \\
\text { threshold. }\end{array}$ & $\begin{array}{l}\text { Points for English ability; } \\
\text { English fluency required } \\
\text { if usual occupation on } \\
\text { ORE list; No minimum } \\
\text { English threshold. }\end{array}$ & $\begin{array}{l}\text { Impact of points for English } \\
\text { ability +impact of changes in } \\
\text { ORE list + cohort effects }\end{array}$ \\
\hline Visa Category & $\begin{array}{l}\text { LSIA2- Pre July 1 1999 } \\
\text { Points for English } \\
\text { ability; English fluency } \\
\text { required if usual } \\
\text { occupation on ORE list; } \\
\text { no minimum English } \\
\text { threshold. }\end{array}$ & $\begin{array}{l}\text { Points for English ability; } \\
\text { English fluency required } \\
\text { if usual occupation on } \\
\text { ORE list; a minimum } \\
\text { English threshold. }\end{array}$ & $\begin{array}{l}\text { Impact of minimum English } \\
\text { threshold }\end{array}$ \\
\hline
\end{tabular}

Note: ORE = Occupations Requiring English.

A differences between differences approach can then be used to establish the net effect of immigration policy. ${ }^{20}$ For example, the comparisons listed in the first row of Table 3 can be analyzed in conjunction with those listed in the second row of the table to help isolate the effect of the expansion of the Occupations Requiring English list. Similarly, the comparisons listed in the first and second rows of Table 3 can be analyzed in conjunction with those listed in the third row of the table to help isolate the effect of using points for English language ability in the selection of immigrants.

\footnotetext{
${ }^{20}$ It is noted that the changes in language requirements could have had an impact on the mix of immigrant source countries, as immigrants from the U.S., U.K. and Canada presumably would have found it easier to meet the entrance requirements. However, changes in source countries due to this reason cannot be disentangled from changes due to other reasons.
} 


\section{Language Skills in the Two Cohorts: Descriptive Analyses}

Table 4 lists information on the English language skills of non-English speaking background immigrants in the two arrival cohorts under investigation. ${ }^{21}$ The figures in normal type are for immigrants arriving in 1993-1995; those in bold type are for immigrants arriving in 1999-2000. In each case the data were collected around 6 months after arrival in Australia. The information is listed for visa category in approximate descending levels of English language proficiency. The final row of data is for Migrating Unit Spouses. Owing to the smaller numbers involved, especially for males, the information for Migrating Unit Spouses is not disaggregated by the visa category of the Principal Applicant.

\section{Table 4}

\section{English-Language Speaking Skills by Visa Category, Non-English Speaking Background Immigrants Arriving in Australia 1993-1995 and 1999-2000}

\section{Males}

\begin{tabular}{|c|c|c|c|c|c|c|c|}
\hline \multirow[b]{2}{*}{ Visa Category } & \multirow[b]{2}{*}{$\begin{array}{l}\text { Unweighted } \\
\text { Sample Size }\end{array}$} & \multirow{2}{*}{$\begin{array}{l}\text { English } \\
\text { Only or } \\
\text { English } \\
\text { Best }\end{array}$} & \multicolumn{4}{|c|}{$\begin{array}{l}\text { English is not the Only or Best Spoken } \\
\text { Language, Speaks English: }\end{array}$} & \multirow[b]{2}{*}{ Total } \\
\hline & & & $\begin{array}{l}\text { Very } \\
\text { Well }\end{array}$ & Well & $\begin{array}{l}\text { Not } \\
\text { Well }\end{array}$ & $\begin{array}{l}\text { Not at } \\
\text { All }\end{array}$ & \\
\hline \multirow[t]{2}{*}{ Independent } & 473 & 23.46 & 27.35 & 39.79 & 9.24 & 0.16 & 100.00 \\
\hline & 192 & 33.80 & 32.62 & 31.87 & 1.71 & 0.00 & 100.00 \\
\hline \multirow{2}{*}{$\begin{array}{l}\text { Skilled-Aust } \\
\text { Sponsored }\end{array}$} & 469 & 18.73 & 16.36 & 32.53 & 27.81 & 4.58 & 100.00 \\
\hline & 140 & 35.54 & 21.20 & 35.51 & 7.41 & 0.33 & 100.00 \\
\hline \multirow{2}{*}{$\begin{array}{l}\text { Business/Employer } \\
\text { Nomination }\end{array}$} & 273 & 19.08 & 20.52 & 28.18 & 25.40 & 6.81 & 100.00 \\
\hline & 182 & 26.14 & 16.22 & 31.91 & 20.39 & 5.34 & 100.00 \\
\hline \multirow[t]{2}{*}{ Family } & 743 & 14.48 & 12.42 & 27.26 & 34.37 & 11.47 & 100.00 \\
\hline & 509 & 12.29 & 13.69 & 19.30 & 39.52 & 15.20 & 100.00 \\
\hline \multirow[t]{2}{*}{ Humanitarian } & 505 & 0.42 & 4.29 & 20.17 & 56.71 & 18.41 & 100.00 \\
\hline & 346 & 1.69 & 5.10 & 16.60 & 55.13 & 21.47 & 100.00 \\
\hline \multirow{2}{*}{$\begin{array}{l}\text { Migrating Unit } \\
\text { Spouse }\end{array}$} & 285 & 11.97 & 11.16 & 21.72 & 37.22 & 17.92 & 100.00 \\
\hline & 199 & 24.26 & 12.99 & 29.06 & 24.46 & 9.23 & 100.00 \\
\hline
\end{tabular}

\footnotetext{
${ }^{21}$ Persons born in the English speaking developed countries (New Zealand, UK, US and Canada) are excluded from the data.
} 


\section{Females}

\begin{tabular}{|c|c|c|c|c|c|c|c|}
\hline \multirow[b]{2}{*}{ Visa Category } & \multirow[b]{2}{*}{$\begin{array}{l}\text { Unweighted } \\
\text { Sample Size }\end{array}$} & \multirow{2}{*}{$\begin{array}{l}\text { English } \\
\text { Only or } \\
\text { English } \\
\text { Best }\end{array}$} & \multicolumn{4}{|c|}{$\begin{array}{l}\text { English is not the Only or Best Spoken } \\
\text { Language, Speaks English: }\end{array}$} & \multirow[b]{2}{*}{ Total } \\
\hline & & & $\begin{array}{l}\text { Very } \\
\text { Well }\end{array}$ & Well & $\begin{array}{l}\text { Not } \\
\text { Well }\end{array}$ & $\begin{array}{c}\text { Not at } \\
\text { All }\end{array}$ & \\
\hline \multirow[t]{2}{*}{ Independent } & 179 & 17.51 & 30.20 & 48.01 & 4.28 & 0.00 & 100.00 \\
\hline & 96 & 40.17 & 30.60 & 26.51 & 2.72 & 0.00 & 100.00 \\
\hline Skilled-Aust & 171 & 24.84 & 19.85 & 32.18 & 20.92 & 2.20 & 100.00 \\
\hline Sponsored & 77 & 39.04 & 19.32 & 26.72 & 14.92 & 0.00 & 100.00 \\
\hline Business/Employer & 69 & 18.05 & 27.19 & 21.08 & 22.85 & 10.83 & 100.00 \\
\hline Nomination & 52 & 9.29 & 18.71 & 26.81 & 33.75 & 11.44 & 100.00 \\
\hline \multirow[t]{2}{*}{ Family } & 1262 & 9.74 & 11.30 & 25.47 & 33.16 & 20.34 & 100.00 \\
\hline & 803 & 12.39 & 12.23 & 25.98 & 35.69 & 13.70 & 100.00 \\
\hline \multirow[t]{2}{*}{ Humanitarian } & 326 & 0.79 & 3.15 & 10.69 & 49.89 & 35.48 & 100.00 \\
\hline & 212 & 0.11 & 3.63 & 14.97 & 52.99 & 28.29 & 100.00 \\
\hline Migrating Unit & 1117 & 11.67 & 9.76 & 22.63 & 36.07 & 19.87 & 100.00 \\
\hline Spouse & 649 & 19.95 & 11.42 & 19.90 & 36.41 & 12.33 & 100.00 \\
\hline
\end{tabular}

Notes: Figures in normal type are for immigrants arriving in 1993-1995, six months after arrival; Figures in bold type are for immigrants arriving in 1999-2000, six months after arrival.

Data exclude persons born in the English speaking developed countries (New Zealand, UK, US and Canada)

Row totals may not sum to 100.00 due to rounding.

Sample Sizes: Cohort 1: 2,463 male PAs, weighted sample of 29,547; 285 male MUSs, weighted sample of 2,842; 2,007 female PAs, weighted sample of 29,653; 1,117 female MUSs, weighted sample of 12,349.

Cohort 2: 1,369 male PAs, weighted sample of 12,261; 199 male MUSs, weighted sample of 1,723; 1,240 female PAs, weighted sample of 12,874; 649 female MUSs, weighted sample of 5,344.

Table 4 shows that immigrants arriving in 1999-2000 in the points tested Independent and Skilled-Australian Sponsored visa categories had English skills superior to those of the earlier arrival cohort. For example, if the categories of "English Only/Best", "English Very Well" and "English Well" are termed "proficient in English", as in the studies by Chiswick, Lee and Miller (2003)(2004a)(2004b), then the proficiency rate for male Independent immigrants rose from 91 percent to 98 percent among immigrants arriving in 1993-1995 and 1999-2000, respectively, among Principal Applicants from non-English speaking countries. Or expressed differently, the nonproficiency rate fell from 9 percent to 2 percent, a 78 percent decline in non-proficiency. For female Independent immigrants, the proficiency rate rose slightly, from 96 percent to 97 percent. Among Independent immigrants, therefore, English proficiency is almost universal. Among Skilled-Australian Sponsored immigrants, the proficiency rate rose from 68 percent to 92 percent for males, and from 77 percent to 85 percent for females. 
In comparison, among the Family immigrants, who are not tested for English skills, the proficiency rate declined from 54 percent to 45 percent for males, and rose marginally from 47 percent to 51 percent for females. These changes could be due to a range of factors, including changes in the birthplace mix of immigrants, and other policy changes, such as the cap on the entry of parents under the Family stream. As noted by Richardson, Robertson and Ilsley (2001), this policy change reduced the average age of immigrants in the Family visa category. Similarly, among Humanitarian visaed immigrants, the proficiency rates remained around 25 percent among males, and increased slightly, from 15 to 19 percent, among females.

These changes in rates of English proficiency for Family and Humanitarian visaed immigrants are thus much more modest than those for Independent and SkilledAustralian Sponsored immigrants, where the English language skill levels jumped appreciably in the more recent cohort.

The English skills of Migrating Unit Spouses are superior among the more recent arrival cohort, with the degree of improvement being in-between that for Independent/Skilled-Australian Sponsored and Family immigrants. The skills of spouses might be expected to have improved over time owing to the interaction of the superior English skills of Principal Applicants and assortative mating, learning English from the more proficient spouse or from children, and the impact of the policy change that introduced points for spouse skills.

The Table 4 data do not distinguish immigrants in the 1999-2000 arrival cohort who were processed according to the pre- and post-July 1, 1999 points tests. For the Skilled-Australian Sponsored category, this omission will not matter, as the weighted sample size for those processed according to the post-July 1, 1999 points tests is very small (four percent of the major visa category). For the Independent visa category, however, the post-July 1999 group is larger, comprising 17 percent of the Independent category. Table 5 presents information on language skills for the pre- and post-July 1, 1999 points tested groups.

Among Independent immigrants, English proficiency is almost universal, given the definition adopted above. Using a more stringent definition, where only the top two English speaking skills categories are defined as proficient in English, there is a slight 
improvement in the English proficiency rate for those processed under the post-July 1, 1999 points tests compared to Independent male immigrants processed according to the pre-July 11999 points tests. Among females, however, those processed under the postJuly 11999 points tests have lower rates of English language proficiency. This is due to a large difference in representation in the "English Only/English Best" category. This difference is likely to be associated with differences in the birthplace mix within the arrival groups. The statistical analyses presented below will control for these effects.

Table 5

English-Language Speaking Skills of Independent Immigrants, Non-English Speaking Background Immigrants Arriving in Australia 1993-1995 and 1999-2000

\section{Males}

\begin{tabular}{|l|c|c|c|c|c|c|}
\hline \multirow{2}{*}{$\begin{array}{l}\text { Visa } \\
\text { Category }\end{array}$} & $\begin{array}{c}\text { English Only } \\
\text { or English } \\
\text { Best }\end{array}$ & \multicolumn{2}{|c|}{ English is not the Only or best Spoken Language, } & \\
\cline { 3 - 6 } & 23.46 & Very Well & Well & Not Well & Not at All & Total \\
\hline 1993-1995 Cohort & 27.35 & 39.79 & 9.24 & 0.16 & 100.00 \\
\hline $\begin{array}{l}\text { 1999-2000 cohort, } \\
\text { pre- July 1 1999 } \\
\text { tests }\end{array}$ & 34.39 & 31.00 & 32.89 & 1.71 & 0.00 & 100.00 \\
\hline $\begin{array}{l}\text { 1999-2000 cohort, } \\
\text { post- July 1 1999 } \\
\text { tests }\end{array}$ & 31.24 & 39.60 & 27.47 & 1.68 & 0.00 & 100.00 \\
\hline
\end{tabular}

\section{Females}

\begin{tabular}{|l|c|c|c|c|c|c|}
\hline \multirow{2}{*}{$\begin{array}{l}\text { Visa } \\
\text { Category }\end{array}$} & \multirow{2}{*}{$\begin{array}{c}\text { English Only } \\
\text { or English } \\
\text { Best }\end{array}$} & \multicolumn{3}{|c|}{ English is not the Only or best Spoken Language, } & \\
\cline { 3 - 6 } & 17.51 & Very Well & Well & Not Well & Not at All & Total \\
\hline $1993-1995$ Cohort & 40.20 & 48.01 & 4.28 & 0.00 & 100.00 \\
\hline $\begin{array}{l}1999-2000 \text { cohort, } \\
\text { pre- July 1 1999 } \\
\text { tests }\end{array}$ & 45.52 & 28.87 & 22.11 & 3.51 & 0.00 & 100.00 \\
\hline $\begin{array}{l}\text { 1999-2000 cohort, } \\
\text { post- July 1 1999 } \\
\text { tests }\end{array}$ & 21.68 & 36.57 & 41.76 & 0.00 & 0.00 & 100.00 \\
\hline
\end{tabular}


English speaking skills improved for most, but not all, immigrants between the first and second interviews. Panel A of Table 6 presents the English-speaking proficiency rate at the time of the wave two interview as a ratio of the rate at the time of the wave one interview. Values greater than one indicate improvement over time in English speaking proficiency. Panel B of the table presents similar information from a comparison of the English-speaking proficiency at the time of the wave three interview with that at the time of the wave one interview.

Table 6

English-Speaking Proficiency Rate in Wave 2 and Wave 3 as a Proportion of English-Speaking Proficiency Rate in Wave 1 by Visa Class, Gender and Cohort, Immigrants from Non-English Speaking Countries

A) Wave 2 versus Wave 1

\begin{tabular}{|l|c|c|c|c|}
\hline \multirow{2}{*}{} & \multicolumn{2}{|c|}{ LSIA1 } & \multicolumn{2}{c|}{ LSIA2 } \\
\cline { 2 - 5 } & Males & Females & Males & Females \\
\hline Independent & 1.031 & 1.010 & 1.019 & 1.033 \\
\hline $\begin{array}{l}\text { Skilled-Australian } \\
\text { Sponsored }\end{array}$ & 1.099 & 1.087 & 1.069 & 1.018 \\
\hline $\begin{array}{l}\text { Business/Employer } \\
\text { Nomination }\end{array}$ & 1.016 & 1.109 & 1.040 & 1.075 \\
\hline Family & 1.204 & 1.165 & 1.382 & 1.159 \\
\hline Humanitarian & 1.652 & 2.392 & 2.032 & 1.739 \\
\hline $\begin{array}{l}\text { Migrating Unit } \\
\text { Spouse }\end{array}$ & 1.383 & 1.207 & 1.076 & 1.266 \\
\hline Total & 1.177 & 1.194 & 1.154 & 1.165 \\
\hline
\end{tabular}

B) Wave 3 versus Wave 1

\begin{tabular}{|l|c|c|}
\hline \multirow{2}{*}{} & \multicolumn{2}{|c|}{ LSIA1 } \\
\cline { 2 - 3 } & Males & Females \\
\hline Independent & 1.042 & 1.025 \\
\hline $\begin{array}{l}\text { Skilled-Australian } \\
\text { Sponsored }\end{array}$ & 1.196 & 1.155 \\
\hline $\begin{array}{l}\text { Business/Employer } \\
\text { Nomination }\end{array}$ & 1.077 & 1.090 \\
\hline Family & 1.354 & 1.251 \\
\hline Humanitarian & 2.183 & 2.841 \\
\hline $\begin{array}{l}\text { Migrating Unit } \\
\text { Spouse }\end{array}$ & 1.531 & 1.427 \\
\hline Total & 1.311 & 1.320 \\
\hline
\end{tabular}


Consider the number in the first cell for male Independent visaed immigrants in the LSIA1. This number, 1.031, indicates that the English proficiency rate at the second interview was 3.1 percent higher than that at the time of the first interview (in fact, rising by almost three percentage points, from 90.5 percent to 93.3 percent).

Table 6, Panel A, has two main features. First, the relative improvement in English speaking proficiency over time is greater for Humanitarian and Family visaed immigrants than for other immigrants. This could be termed an initial conditions effect: these immigrants have relatively poor English skills at the time of entry into Australia, and hence large proportional changes are easier for them than for immigrants in the skilled categories where proficiency rates are initially much higher. It might also reflect greater investments in English language proficiency among those who arrive with the lowest proficiency, especially refugees who might not have prepared for the move by investing in English language skills in their origin and who are less favorably selected for immigration. ${ }^{22}$

Second, comparing immigrants in LSIA2 with those in LSIA1, there are two changes of note. The first of these is the limited improvement between the first and second interviews in English-speaking skills among female Independent visaed immigrants in LSIA2. It is apparent from Table 4 that this group had an unusually high rate of English speaking proficiency at the time of arrival, and the Table 6 findings could again be a reflection of an initial conditions effect. The second feature is the stronger improvement in English speaking skills in LSIA2 among immigrants in the SkilledAustralian Sponsored category.

The information in Panel B of Table 6 show that there were further improvements in the English-speaking proficiency of immigrants in all visa classes by the time of the third interview. The relative improvement, however, was greater for those immigrants with poorer English skills at the time of entry into Australia.

\footnotetext{
${ }^{22}$ A similar pattern of an inverse relationship between the initial level and the subsequent increase is found for immigrant earnings - see, for example, Chiswick (1979).
} 
Similar analyses were conducted for English reading and writing skills, and selected Tables are presented in Appendix B. ${ }^{23}$ The major findings described above carry over to these other skills.

\section{Econometric Analyses}

The multivariate analyses presented below are based on the model of dominant language skills developed by Chiswick and Miller (see, particularly, Chiswick and Miller (1992)(1995)(1998a)). This model has previously been applied to the LSIA1 by Chiswick, Lee and Miller (2003)(2004a)(2004b). In the model an immigrant's language skills are represented by a binary indicator, defined to be equal to one where the immigrant's only or best spoken language is English, or where another language is the best spoken, the immigrant speaks English very well or well. All other proficiency states are defined to be equal to zero.

This is the measure of proficiency introduced above when discussing Tables 4 to 6. It is noted that this involves aggregating some of the underlying language categories, and may be seen as involving a loss of information. However, Kominski (1989, p.336) has observed in relation to US Census language data on how well individuals speak English that "The data do not detail a firm discrimination between the four different categories of the "how well" question, but there are clear differences between the very best speakers of English and the very worst". This suggests that the use of the binary indicator will not be a major limitation. Estimates are, however, presented below for an ordered probability model that utilizes all categories of English skills available in the data set.

Drawing on Chiswick and Miller (1992, 1995, 1998a), the immigrant's proficiency in English (speaking, reading or writing) skills (LANG) is modeled as:

$$
\mathrm{LANG}=\mathrm{f}(\text { economic incentives, efficiency, exposure }) .
$$

The empirical counterpart of this general model has typically been developed using institutional information (e.g., visa category), demographic characteristics (e.g.,

\footnotetext{
${ }^{23}$ Appendices $\mathrm{B}$ through $\mathrm{E}$ are available from the authors upon request.
} 
birthplace, age at migration, educational attainment), known activities of the immigrants (e.g., whether they visited Australia prior to migration, whether they expected to leave Australia permanently) and behavioral variables constructed from information on the immigrants' birthplace and mother tongue (e.g., geographic distance of the country of origin from Australia, linguistic distance of the mother tongue from English) (see Chiswick Lee and Miller (2003)(2004a)(2004b)).

The emphasis in this paper is on the comparisons across visa categories of differences in English skills at the time of immigration, and of the development of these skills with duration of residence in Australia. To facilitate this focus, the variables with behavioral interpretations that have been used in place of birthplace are not included in the estimating equation. This should not be seen as a limitation, as the analyses reported by Chiswick Lee and Miller (2003)(2004a)(2004b), and by Chiswick and Miller (1996)(1999), show that the birthplace-related variables have limited explanatory power in analyses for Australia. This contrasts sharply with the situation when similar models have been estimated for the U.S. and Canada, where there is greater specificity on birthplace and languages spoken. Moreover, unless one is specifically interested in behavioral interpretation from knowing country of origin, which is not the purpose of this study, Chiswick and Miller (1996)(1999) show that birthplace dummy variables are fine.

Economic incentives for the acquisition of English skills among immigrant arrivals in Australia depend on the labor market, consumption and community benefits expected to be associated with these skills, and the length of time over which these benefits are expected to accrue. Measurement of these benefits for inclusion in a model of English language skills has generally proven intractable to date. Hence most attention in empirical research has focused on the expected length of time over which the wage and other gains are to be realized. Two sets of variables may be used to capture this influence. The first of these is information on whether immigrants expected to leave Australia permanently. The second is a set of birthplace variables that serve as a proxy for the probability of return migration: birthplace can be regarded as an indicator of the incidence of return migration since origins differ in the extent of permanent and sojourner migration. 
Efficiency refers to the extent to which a given amount of exposure to English produces language proficiency. It has been shown in numerous studies that proficiency is enhanced by a higher level of education and by migration while young (see Long (1990) and Service and Craik (1993) on the age effects in language attainment). ${ }^{24}$

Exposure has three dimensions. These are: exposure prior to migration, time units of exposure in the destination country, and the intensity of exposure per unit of time in the destination.

Two measures of exposure prior to migration were considered by Chiswick, Lee and Miller (2003)(2004a)(2004b). The first of these is constructed from information on the extent of cross country/culture contact in the country of origin. Immigrants with cross-cultural contact prior to immigration are more likely to have been exposed to English, or at least have a relatively favorable disposition towards other cultures that may be associated with a greater preparedness to learn English.

A second variable is given by whether the immigrant visited Australia prior to migrating. Immigrants would be exposed to English during such visits, the visits could be indicative of a greater degree of planning for the migration, and with greater knowledge gained through such visits there may be a higher likelihood of staying. It is therefore expected that immigrants who visited Australia prior to migrating would have English skills superior to the skills of those who did not visit Australia.

Time units of exposure in the destination country (or years since migration) play an important role in the studies of language skills based on cross-sectional data (e.g., Chiswick and Miller (1995)). As the current study is based on longitudinal data, this effect is captured by dummy variables for each of the waves of data collection, though in the initial set of estimates where the aim is to mimic the cross-sectional approach, a duration of residence variable (weeks since migration) is used.

The intensity of exposure per unit of time in Australia is more complex. It will depend on the characteristics of the person's home and location. The home environment is measured in most analyses through variables for the number and ages of children, and

\footnotetext{
${ }^{24}$ Another efficiency variable is the extent of the difference between the origin language and English. This behavioral variable is not used in the current study as many of its effects are captured by the birthplace variables. For a development of this work, see Chiswick and Miller (2004).
} 
for the birthplace or language skills of the spouse. In the Longitudinal Survey of Immigrants to Australia there is information both on the family structure and on whether children live with their parents. Moreover, the survey contains details on whether other people who were part of the "migrating unit" live with the respondent. Hence, the following variables are included in the language model: whether a spouse who was part of the migrating unit is present in the household (MUS); whether a spouse who was not part of the migrating unit is present in the household (OS); whether there are children in the household (KIDS); whether other relatives who gained approval to migrate to Australia as part of the Principal Applicant's migration application are present in the household (MUR); whether other relatives are present in the household (OR).

The information on the immigrant's living arrangements can be complemented with information on the main reason the immigrant chose his/her State of initial settlement in Australia. Where "family/friends" is the main reason for the choice of location, it is expected that the immigrant will have access to an ethnic network. The availability of this ethnic network can reduce the exposure to, and practice in using, English, and hence reduce proficiency.

The empirical counterpart to equation (4) used in this research is:

$\mathrm{LANG}=\mathrm{f}$ (cohort, wave, visa category, age at migration, education, gender, birthplace, preparation for migration, expected duration in destination, cross country/culture contact in country of origin, family structure, reasons for choice of state of initial settlement).

All variables are defined in Appendix C.

This general model is applied in this study as follows. Denote the above explanatory variables other than cohort and wave by the vector X, and let W1 represent the first interview, W2 the second interview, and W3 the third interview. Then the actual equation to be estimated is:

$$
\begin{aligned}
L A N G_{i t}= & \alpha_{0}+\beta_{1} X_{i t}+\gamma_{2} W 2_{i t}+\gamma_{3} W 3_{i t}+\delta_{2} W 2_{i t} X_{i t}+\delta_{3} W 3_{i t} X_{i t}+\phi_{1} L S I A 2_{i t}+ \\
& \phi_{2} L S I A 2_{i t} W 2_{i t}+\varphi_{1} L S I A 2_{i t} X_{i t}+\varphi_{2} L S I A 2_{i t} W 2_{i t} X_{i t}+\varepsilon_{i t}
\end{aligned}
$$


where $\mathrm{i}$ is the individual and $\mathrm{t}$ is the time of the interview. In other words, the basic estimating equation is applied to a sample pooled across all waves of the data sets (three waves for LSIA1, two waves for LSIA2) and across surveys (i.e., both LSIA1 and LSIA2), with a full set of interaction terms between waves of data (W2, W3) and surveys (LSIA2) and the explanatory variables (X). In this general representation of the estimation equation, $\beta_{1}$ will capture the impact of the $\mathrm{X}$ characteristics on the distribution of English language skills for the first cohort of immigrants (LSIA1) at the time of the first set of interviews, approximately six months after arrival. The $\gamma_{j}$ 's will capture general shifts on the mean levels of English skills between the first and subsequent interviews for this cohort of immigrants, and as such can be viewed as capturing the impact of duration of residence in Australia. The $\delta$ 's will capture the changes in English skills for immigrants in the LSIA1 with the $\mathrm{X}$ characteristics with time in Australia. In other words, these parameters will capture the learning or deterioration of language skills for this cohort with time in the destination country. ${ }^{25}$

As the data are not only pooled across waves of interviews within a survey, but across the two cohorts of immigrants, variables and interaction terms for the second cohort of immigrants need also to be included in the specification. $\phi_{1}$ measures the mean difference in language skills between immigrants in the second cohort and those in the first cohort, ceteris paribus. Hence it will capture cohort effects. $\phi_{2}$ will measure the differential growth in language skills between the first two interviews for immigrants in LSIA2 compared to immigrants in LSIA1. Likewise, $\varphi_{1}$ will record the differential for immigrants in LSIA2 compared to immigrants in LSIA1 of the impact of the $\mathrm{X}$ characteristics on the initial distribution of language skills. Finally, $\varphi_{2}$ will measure the differential in learning or deterioration in language skills with the $\mathrm{X}$ characteristics with

\footnotetext{
${ }^{25}$ Chiswick and Miller (1998b), for example, report that up to 15 percent of a group of legalized aliens in the US who reported that they could read or speak English in specific situations indicated that they could not do so three years later. It could not be determined whether this was an actual deterioration in skills, a change in the reference point as to what is speaking very well or well, or merely measurement error in either situation.
} 
time in the destination for immigrants in LSIA2 in comparison with immigrants in LSIA1.

Person-specific fixed effects can also be incorporated into this model through the addition of the term $\lambda \mu_{i}$. The probit fixed effects model can, however, only be estimated on a sub-sample comprising individuals who change language state across waves of data collection. Given this limitation, only brief comments from the application of fixed effects estimators will be provided.

Table 7 presents the estimates for three different models, namely an OLS model, a Probit model and an Ordered Probit model. The first two models are based on a binary dependent variable, being the measure of proficiency developed earlier. The third model is based on all of the categories of English skills presented in the data.

This initial set of estimates is obtained from a sample pooled across waves of data for each cohort of immigrants, and across the two cohorts. As the purpose of this presentation is to provide a benchmark set of results that may be compared with the literature (which has largely been based on cross-sectional analyses), the estimating equation does not include a variable recording the cohort of arrival. Moreover, to enhance comparability with past research, a continuous period of residence (weeks in Australia) is used in place of dummy variables for the wave of data collection.

The OLS model is often used in the study of probability models for the ease of interpretation it offers. The deficiencies of the model (prediction outside the unit interval, heteroscedastic error structure) are well known. Binary probit estimation offers a convenient means of accommodating the underlying nature of the dependent variable in the analysis, though, being based on only two categories of English proficiency, it does not make full use of the data on English skills available in the survey. The ordered probit approach recognises both the categorical nature of the English skills data and utilises the full extent of the information available. This estimation procedure is appropriate when there is a natural ordering to the data, which is the case with the English skills data. However, it does assume that the impact of any variable on the probit index does not vary across the language categories (SAS Institute Inc (1994)). 
Table 7

Models of English Speaking Skills, 15 - 64 Year Old Males and Females from NonEnglish Speaking Countries

\begin{tabular}{|c|c|c|c|}
\hline Variable & $\begin{array}{l}\text { OLS } \\
\text { (i) }\end{array}$ & $\begin{array}{l}\text { Probit } \\
\text { (ii) }\end{array}$ & $\begin{array}{l}\text { Ordered Probit } \\
\text { (iii) }\end{array}$ \\
\hline Constant & $\begin{array}{l}0.091 \\
(3.07)\end{array}$ & $\begin{array}{l}-1.214 \\
(9.39)\end{array}$ & $\begin{array}{l}-0.001 \\
(0.01)\end{array}$ \\
\hline $\begin{array}{l}\text { Visa Category (Independent) } \\
\text { Humanitarian (Refugee) }\end{array}$ & $\begin{array}{l}-0.239 \\
(18.53)\end{array}$ & $\begin{array}{l}-1.171 \\
(18.56)\end{array}$ & $\begin{array}{c}-0.691 \\
(18.19)\end{array}$ \\
\hline Family & $\begin{array}{l}-0.163 \\
(13.78)\end{array}$ & $\begin{array}{l}-1.066 \\
(15.35)\end{array}$ & $\begin{array}{l}-0.466 \\
(11.83)\end{array}$ \\
\hline Skilled-Australian Sponsored & $\begin{array}{l}-0.048 \\
(4.31)\end{array}$ & $\begin{array}{l}-0.507 \\
(7.34)\end{array}$ & $\begin{array}{l}-0.079 \\
(2.03)\end{array}$ \\
\hline Business Skills/ENS ${ }^{(b)}$ & $\begin{array}{l}-0.150 \\
(12.96)\end{array}$ & $\begin{array}{l}-1.014 \\
(11.57)\end{array}$ & $\begin{array}{l}-0.384 \\
(6.99)\end{array}$ \\
\hline Age at Migration & $\begin{array}{l}-0.005 \\
(8.53)\end{array}$ & $\begin{array}{l}-0.019 \\
(12.88)\end{array}$ & $\begin{array}{l}-0.016 \\
(14.19)\end{array}$ \\
\hline Education & $\begin{array}{c}0.050 \\
(48.61)\end{array}$ & $\begin{array}{c}0.185 \\
(40.88)\end{array}$ & $\begin{array}{c}0.163 \\
(53.91)\end{array}$ \\
\hline Female & $\begin{array}{l}-0.032 \\
(4.64)\end{array}$ & $\begin{array}{r}-0.099 \\
(3.42)\end{array}$ & $\begin{array}{l}-0.104 \\
(5.18)\end{array}$ \\
\hline $\begin{array}{l}\text { Cross Country/Culture Contact in } \\
\text { Former Home Country }\end{array}$ & $\begin{array}{c}0.089 \\
(12.92)\end{array}$ & $\begin{array}{c}0.338 \\
(12.59)\end{array}$ & $\begin{array}{c}0.316 \\
(16.43)\end{array}$ \\
\hline Previously Visited Australia & $\begin{array}{c}0.194 \\
(27.44)\end{array}$ & $\begin{array}{c}0.854 \\
(25.73)\end{array}$ & $\begin{array}{c}0.743 \\
(34.19)\end{array}$ \\
\hline $\begin{array}{l}\text { Main Reason for Choosing State } \\
\text { Settled was Family/Friends }\end{array}$ & $\begin{array}{l}-0.042 \\
(5.35)\end{array}$ & $\begin{array}{r}-0.260 \\
(6.60)\end{array}$ & $\begin{array}{l}-0.122 \\
(4.85)\end{array}$ \\
\hline Contact with Ethnic Agencies & $\begin{array}{l}-0.029 \\
(2.91)\end{array}$ & $\begin{array}{l}-0.123 \\
(3.14)\end{array}$ & $\begin{array}{l}-0.105 \\
(3.80)\end{array}$ \\
\hline Expect to Stay in Australia & $\begin{array}{l}0.024 \\
(1.43)\end{array}$ & $\begin{array}{l}0.155 \\
(2.19)\end{array}$ & $\begin{array}{l}0.154 \\
(3.18)\end{array}$ \\
\hline $\begin{array}{l}\text { Family Structure } \\
\text { MUS }^{(\mathrm{c})}\end{array}$ & $\begin{array}{l}-0.036 \\
(3.53)\end{array}$ & $\begin{array}{l}-0.177 \\
(3.74)\end{array}$ & $\begin{array}{l}-0.062 \\
(1.99)\end{array}$ \\
\hline $\operatorname{OS}^{(\mathrm{d})}$ & $\begin{array}{l}0.003 \\
(0.30)\end{array}$ & $\begin{array}{l}0.074 \\
(1.58)\end{array}$ & $\begin{array}{l}0.025 \\
(0.77)\end{array}$ \\
\hline $\operatorname{KIDS}^{(\mathrm{e})}$ & $\begin{array}{l}-0.044 \\
(6.03)\end{array}$ & $\begin{array}{l}-0.175 \\
(5.87)\end{array}$ & $\begin{array}{l}-0.141 \\
(6.66)\end{array}$ \\
\hline $\operatorname{MURS}^{(\mathrm{f})}$ & $\begin{array}{l}-0.003 \\
(0.19)\end{array}$ & $\begin{array}{r}-0.019 \\
(0.31)\end{array}$ & $\begin{array}{l}0.095 \\
(2.05)\end{array}$ \\
\hline $\mathrm{OR}^{(\mathrm{g})}$ & $\begin{array}{l}-0.065 \\
(8.50)\end{array}$ & $\begin{array}{r}-0.205 \\
(6.82)\end{array}$ & $\begin{array}{l}-0.237 \\
(10.99)\end{array}$ \\
\hline Weeks in Australia/100 & $\begin{array}{c}0.089 \\
(17.13)\end{array}$ & $\begin{array}{c}0.353 \\
(15.92)\end{array}$ & $\begin{array}{c}0.251 \\
(16.54)\end{array}$ \\
\hline
\end{tabular}




\begin{tabular}{lccc}
\hline Birthplace (Europe and USSR) & & & \\
Oceania/Antarctica & 0.329 & 1.879 & 1.692 \\
& $(22.65)$ & $(15.31)$ & $(29.31)$ \\
Middle East and North Africa & 0.012 & 0.101 & 0.069 \\
& $(0.96)$ & $(2.27)$ & $(2.08)$ \\
Southeast Asia & 0.049 & 0.255 & 0.375 \\
& $(5.10)$ & $(6.61)$ & $(13.66)$ \\
Northeast Asia & -0.133 & -0.566 & -0.552 \\
& $(12.33)$ & $(12.73)$ & $(17.86)$ \\
Southern and Central Asia & 0.165 & 0.724 & 0.979 \\
& $(15.16)$ & $(13.62)$ & $(28.65)$ \\
South/Central America and & -0.069 & -0.306 & -0.204 \\
Caribbean & $(2.88)$ & $(3.44)$ & $(3.14)$ \\
Other Africa (Sub-Saharan Africa) & 0.188 & 0.920 & 1.221 \\
& $(11.94)$ & $(10.99)$ & $(22.58)$ \\
$\mu_{1}$ & (a) & (a) & 1.646 \\
$\mu_{2}$ & & & $(20.52)$ \\
$\mu_{3}$ & (a) & (a) & 2.879 \\
$\chi^{2}$ & & & $(27.04)$ \\
Prediction Success Rate (\%) & & (a) & 3.656 \\
Adjusted $R^{2}$ & (a) & 7423.35 & $(231.92)$ \\
F - test & 0.391 & 79.30 & 9799.89 \\
Sample Size & 386.35 & (a) & 47.81 \\
\hline
\end{tabular}

Notes: Numbers in parentheses are ' $t$ ' statistics; No statistical control for cohort, and with a duration of residence variable (weeks in Australia) in place of wave dummy variables.
(a) Variable not relevant.
(b) ENS denotes Employer Nomination Scheme.
(c) Whether a spouse who was part of the migrating unit is present in the household.
(d) Whether a spouse who was not part of the migrating unit is present in the household.
(e) Whether there are children in the household.
(f) Whether other relatives who gained approval to migrate to Australia as part of the Principal Applicant's migration application are present in the household.
(g) Whether other relatives are present in the household.

Source: Longitudinal Survey of Immigrants to Australia, Cohorts I and II.

The estimated coefficients from the three models listed in Table 7 are not numerically comparable. However, given that the partial effect for the $k^{\text {th }}$ variable in the probit model is given as $\phi(X \beta) \beta_{k}$, broad comparisons can be drawn between the estimates for the OLS model (which record marginal effects) and the Probit model with the following approximation: 


$$
\beta_{L P}=a \beta_{\phi}
$$

where $\beta_{L P}$ denotes the estimates of the parameters for the linear probability (OLS) model, $\beta_{\phi}$ is the estimates of the parameters for the probit model and $a$ is the probability distribution function for the standard normal evaluated at an index that equates to the mean level of English proficiency in the sample (that is, $a=\phi\left(\Phi^{-1}(\overline{L A N G})\right)$ ). For example, for the sample in Table 7 the mean level of English proficiency is 0.639 and the corresponding probit index that would generate this mean is 0.356. Accordingly, the value of $a$ (found from $\phi(X \beta)$ ) to be used in the comparisons of the first two columns of results is 0.375 . It is seen using this approximation that the majority of the estimates for the OLS and Probit models are comparable. However, there are some differences, for example the coefficients associated with the variables 'Skilled-Australian Sponsored', 'Previously Visited Australia', and 'Other Africa (Sub-Saharan Africa)'. These differences point to some advantages to the Probit specification.

The table lists the estimates for variables on four classes of visas (Humanitarian Visa, Family Visa, Skilled-Australian Sponsored Visa, and Business Skills/ENS Visa), with the benchmark group for visa category being the Independent visa. The ranking of coefficients (Independent Visa, Skilled-Australian Sponsored Visa, Business Skills/ENS Visa, Family Visa, and Humanitarian Visa) is consistent across the three methods of estimation employed. The negative coefficients on the four visa category variables indicate that immigrants who entered Australia using these visas have lower English speaking skills as compared to those with Independent visas. This is presumably due to the selection criteria used for entry into Australia, where English speaking skills are essential for applicants entering under an Independent visa. On the other hand, those who entered under Humanitarian visas are the least likely to have English speaking skills since these skills are not required for visa acquisition, and non-economic motives are strongly influencing their migration decisions.

The estimated coefficient on the variable for age at migration is negative in each column of results. This shows that English speaking skills decrease with age at migration. 
The OLS result in column (i) indicates that the level of English speaking skills decreases by 0.5 percentage points with each additional year of age at migration, with a similar impact being recorded for the Probit model. It is suggested that this type of effect is associated with learning skills that decrease with age.

The education level has a positive impact on the immigrants' English speaking proficiency. That is, immigrants with a higher level of educational attainment have a higher level of English speaking proficiency, by 5 percentage points per year of schooling in the OLS analysis. This partial effect is particularly strong, as can be seen by comparing the estimated effects associated with age at migration and educational attainment: each additional year of education is the equivalent in impact on English skills to 10 fewer years of age at migration. This impact associated with educational attainment is far greater than might be expected on the basis of the points awarded for these attributes in immigrant selection in Australia (see Tables 1 and 2 above). The relationship between the probability of being proficient in English and educational attainment computed from the probit model is illustrated in Figure 1. 
Figure 1

\section{Standardised Relationship between the Probability of being Proficient in English and Educational Attainment}

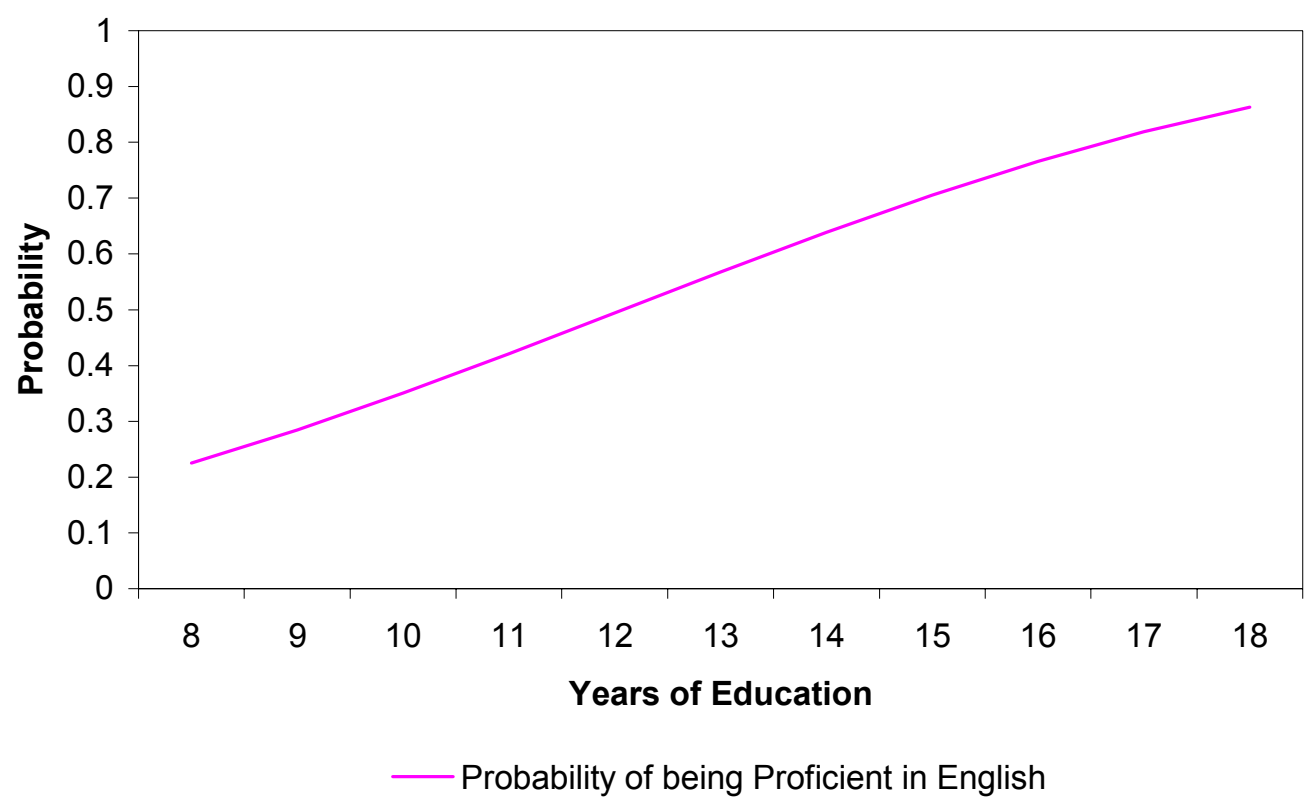

Female immigrants have lower English speaking skills as compared to their male counterparts. The estimated coefficient in the OLS model indicates a 3.2 percentage point gender differential in English language proficiency. Compared to some of the other estimated effect, (e.g. two thirds of a year of schooling), this gender effect is small.

Both the variables for the 'cross country/culture contact in former home country' and 'previously visited Australia' have positive coefficients. This implies that immigrants' exposure to Australia before migration is associated with a higher level of English speaking skills after migrating to Australia as compared to those who have never been exposed to the English language before migration. Previous exposure to Australia presumably enables the immigrants to adapt more quickly and pick up the language more easily.

The presence of family and friends as the main factor influencing location decisions within Australia has a negative impact on English speaking proficiency in each of the three models examined. This impact may arise because the presence of these family members and friends facilitates communication in the immigrants' mother tongue 
and hence reduces the incentive to learn English or the exposure to English. The effect of this variable is similar to that of the variable that records whether immigrants have had contact with ethnic agencies since arrival in Australia. Immigrants who have had such contact appear to have lower English speaking proficiency, presumably because they have less incentive and possibly fewer chances to speak English when they remain within their ethnic groups.

In comparison to these negative influences on English skills, the variable that captures the immigrants' expectation to stay in Australia is associated with a positive effect. The expectation to stay is clearly a motivation to develop a better grasp of the English language. ${ }^{26}$

In addition, the variable that records the weeks of residence in Australia is positive; this shows that the English speaking skills of the immigrants will improve with the duration of stay in Australia. In these data on recent arrivals, proficiency improves by 9 percentage points per 100 weeks in Australia, or 4 to 5 percentage points per year.

There are five variables used to capture the effects of different compositions of the immigrants' household. ${ }^{27}$ The results show that the presence of a spouse in the household who was part of the migrating unit, the presence of children in the household and the presence of other relatives in the household have negative impacts on the immigrants' English Speaking skills. In contrast, the OLS and ordered probit models show an insignificant positive effect for the presence in the household of other relatives who gained approval to migrate to Australia as part of the Principal Applicant's migration application.

These models also included seven birthplace dichotomous variables, namely 'Oceania/Antarctica', 'Middle East and North Africa', 'Southeast Asia', 'Northeast Asia', 'Southern and Central Asia', 'South/Central America and Caribbean', and 'Other Africa (sub-Saharan Africa)'. The benchmark group for these dummies is the birthplace

\footnotetext{
${ }^{26}$ However, the estimated coefficient on this variable in the OLS model is statistically insignificant.

${ }^{27}$ The variable that records whether a spouse who was not part of the migrating unit is present in the household is statistically insignificant across all estimating models.
} 
group of Europe and the USSR. All of the dummies are positive and statistically significant except those for 'Northeast Asia' and 'South/Central America and Caribbean'. ${ }^{28}$ The positive sign on the estimated coefficients show that immigrants who were born in these birthplace groups will have higher English speaking skills than those born in Europe and the USSR. On the other hand, those born in 'Northeast Asia' and 'South /Central America and Caribbean' will be less proficient in English speaking compared to immigrants born in Europe and the USSR.

The estimated thresholds for the Ordered Probit are each statistically significant. This indicates that the underlying language categories recognised in the data are distinct, and as such this is an argument against the use of a binary dependent variable such as that analyzed in columns (i) and (ii). However, tests ${ }^{29}$ show that the assumption of equal slope effects across the English categories does not hold, implying that the parsimony in parameters of this model (compared, for example, to a multinomial probit model) is achieved at a cost. Another possible limitation is that the estimated impacts in the Ordered Probit are difficult to interpret, as a positive (negative) coefficient can only be unambiguously associated with an increase (decrease) in membership of the highest ranked category and a decrease (increase) in membership of the lowest ranked category. This difficulty can be overcome by computing predicted distributions across the language categories for the values of variables under consideration and comparing these distributions and associating differences in the distributions with changes in the values of the variables. Table 8 presents predictions for the standardised distribution of immigrants across the five English skills categories recognised in the data by level of education. ${ }^{30}$

\footnotetext{
${ }^{28}$ Except for the estimated coefficient of variable on 'Middle East and North Africa' in the OLS model.

${ }^{29}$ See SAS Institute Inc (1994) for details on the test implemented.

${ }^{30}$ These prediction are calculated at the mean values for all variables in the ordered probit model other than educational attainment.
} 
Table 8

Predictions of the Standardised Distribution of Immigrants across English Skills Categories

\begin{tabular}{|c|c|c|c|c|c|}
\hline \multirow{2}{*}{$\begin{array}{l}\text { Level of } \\
\text { Education } \\
\text { (Year) }\end{array}$} & \multirow{2}{*}{$\begin{array}{c}\text { English } \\
\text { Only or } \\
\text { English } \\
\text { Best }\end{array}$} & \multicolumn{4}{|c|}{ English is not the Only or Best Spoken Language, Speaks English: } \\
\hline & & Very Well & Well & Not Well & Not at All \\
\hline 8 & 0.006 & 0.034 & 0.261 & 0.569 & 0.131 \\
\hline 10 & 0.014 & 0.063 & 0.345 & 0.504 & 0.074 \\
\hline 12 & 0.030 & 0.105 & 0.416 & 0.411 & 0.038 \\
\hline 14 & 0.060 & 0.158 & 0.457 & 0.307 & 0.018 \\
\hline 16 & 0.109 & 0.216 & 0.457 & 0.210 & 0.008 \\
\hline 18 & 0.183 & 0.267 & 0.416 & 0.131 & 0.003 \\
\hline
\end{tabular}

Source: Authors' calculations based on Table 7, column 3.

The data in Table 8 illustrate clearly the marked improvement in English speaking skills with educational attainment. Few of the least-well educated are predicted to speak English only or have English as their best spoken language, and only four percent are proficient in English under the 'proficient'/'not proficient' distinction introduced above. Fully 70 percent have extremely limited English skills ('not well' or 'not at all'). In comparison, among those with 18 years of education, the predictions indicate that 18 percent speak English only or English best and a further 27 percent speak a language other than English at home and speak English 'very well'. Only 13 percent are in the most limited English skills categories. The improvements in English skills with level of education are shown to be associated with a rapid decline in the 'not at all' category, and an equally pronounced shift away from the 'not well' category. Up to 16 years of education, additional years of schooling are associated with greater representation in the middle of the distribution, the speaks English 'well' category.

The patterns described in Table 7 are reasonably well known, being fully consistent with the growing body of literature on the determinants of immigrants' dominant language skills (see Chiswick and Miller 1992, 1995, 1998a). However, the literature has largely been based on cross-sectional data, and the Table 7 analyses have mimicked this approach to facilitate the comparisons made. The remainder of this section 
shows the insights that can be gained from following immigrants through time via a longitudinal study. As noted previously, the panel used is quite short, being three years for the first cohort from the LSIA and only one year for the second cohort. Nevertheless, given the limited availability of longitudinal data sets, the analyses can be instructive, not only for the results obtained but also for the insights that can be offered into future data collection needs. Moreover, the numerous cross-sectional studies for several countries (US, Canada, Israel, as well as Australia) indicate that the annual improvement in language skills is greatest during the first few years in the destination.

Table 9 presents estimates corresponding to equation (6). These estimates are for a probit model. Estimates from OLS and ordered probit models corresponding to equation (6) are presented in Appendix D.

The estimates listed for wave one of cohort one are main effects: all other estimates are differences in coefficients for the particular wave of data and cohort. For example, consider the figures in the row for the Humanitarian variable. The first figure, 1.390 , is the effect on the probit index for English skills among immigrants in wave one of the first cohort associated with arriving in Australian on a Humanitarian visa compared to arrival on an Independent visa, which is the benchmark. This figure shows that those on a Humanitarian visa have significantly poorer English speaking skills than the benchmark group. The second figure, 0.468 , indicates how this effect differs for these immigrants (Humanitarian versus Independent) one year later at the time of their second interview (there is an increase in the relative English speaking skills of those arriving under a Humanitarian visa, which is statistically significant $\left.-{ }^{\prime} t '=2.91\right)$. Similarly, the third figure indicates how the impact differs for the same group of immigrants a further two years later, at the time of their third interview (a larger improvement in the relative English speaking skills of those arriving under a Humanitarian visa, which is highly significant $-' t '=3.69)$. The fourth figure of -0.439 shows how the links between Humanitarian visas and English skills differ between immigrants from the second cohort after approximately six months residence in Australia and their counterparts in the first cohort after a similar length of time in Australia. It shows that there is a relatively larger gap between the English speaking skills of those on Humanitarian visas and the Independent visaed immigrants in the second cohort, but this is statistically significant 
only at the 10 percent level $(' t '=1.79)$. Finally, the fifth figure records the difference in the links between Humanitarian visas and English skills for immigrants in cohort two at the time of their second interview compared to Cohort 1, Wave 1. This shows a slight worsening of relative position, which is at the margin of statistical significance (' $\mathrm{t}$ ' $=1.79$ ). All other entries in this table are to be read and interpreted in this way.

Table 9

Probit Model of English Speaking Skills, 15-64 Year Old Males and Females from Non-English Speaking Countries

\begin{tabular}{|c|c|c|c|c|c|}
\hline \multirow[b]{2}{*}{ Variable $\left(X_{i}\right)$} & \multicolumn{3}{|c|}{ Cohort 1} & \multicolumn{2}{|c|}{ Cohort 2} \\
\hline & $\beta_{1} X_{i}$ & $\delta_{2} W{ }_{i} X_{i}$ & $\delta_{3} W 3_{i} X_{i}$ & $\varphi_{1} L S I A 2_{i} X_{i}$ & $\varphi_{2}{ }^{L S I A 2}{ }_{i} W 2_{i} X_{i}$ \\
\hline $\begin{array}{l}\text { Constant/wave/cohort } \\
\text { effects }\end{array}$ & $\begin{array}{l}-1.987 \\
(8.91)\end{array}$ & $\begin{array}{l}1.210 \\
(3.70)\end{array}$ & $\begin{array}{l}1.781 \\
(4.76)\end{array}$ & $\begin{array}{l}1.625 \\
(1.95)\end{array}$ & $\begin{array}{l}2.568 \\
(3.93)\end{array}$ \\
\hline \multicolumn{6}{|c|}{ Visa Category (Independent) } \\
\hline $\begin{array}{l}\text { Humanitarian } \\
\text { (Refugee) }\end{array}$ & $\begin{array}{l}-1.390 \\
(13.08)\end{array}$ & $\begin{array}{l}0.468 \\
(2.91)\end{array}$ & $\begin{array}{l}0.655 \\
(3.69)\end{array}$ & $\begin{array}{l}-0.439 \\
(1.79)\end{array}$ & $\begin{array}{l}-0.759 \\
(1.79)\end{array}$ \\
\hline Family & $\begin{array}{l}-0.943 \\
(7.58)\end{array}$ & $\begin{array}{l}0.046 \\
(0.25)\end{array}$ & $\begin{array}{l}0.174 \\
(0.90)\end{array}$ & $\begin{array}{l}-1.016 \\
(3.54)\end{array}$ & $\begin{array}{l}-1.406 \\
(3.14)\end{array}$ \\
\hline $\begin{array}{l}\text { Skilled-Australian } \\
\text { Sponsored }\end{array}$ & $\begin{array}{l}-0.619 \\
(5.34)\end{array}$ & $\begin{array}{l}0.104 \\
(0.59)\end{array}$ & $\begin{array}{l}0.280 \\
(1.44)\end{array}$ & $\begin{array}{l}0.170 \\
(0.65)\end{array}$ & $\begin{array}{l}-0.307 \\
(0.69)\end{array}$ \\
\hline $\begin{array}{l}\text { Business } \\
\text { Skills/ENS }\end{array}$ & $\begin{array}{l}-0.985 \\
(6.09)\end{array}$ & $\begin{array}{l}0.101 \\
(0.41)\end{array}$ & $\begin{array}{l}0.173 \\
(0.64)\end{array}$ & $\begin{array}{l}-0.422 \\
(1.52)\end{array}$ & $\begin{array}{l}-1.095 \\
(2.43)\end{array}$ \\
\hline Age at Migration & $\begin{array}{l}-0.006 \\
(2.24)\end{array}$ & $\begin{array}{l}-0.012 \\
(3.02)\end{array}$ & $\begin{array}{l}-0.027 \\
(6.26)\end{array}$ & $\begin{array}{l}-0.021 \\
(3.45)\end{array}$ & $\begin{array}{l}-0.026 \\
(4.08)\end{array}$ \\
\hline Education & $\begin{array}{c}0.190 \\
(22.29)\end{array}$ & $\begin{array}{l}-0.006 \\
(0.47)\end{array}$ & $\begin{array}{l}0.014 \\
(1.07)\end{array}$ & $\begin{array}{l}-0.031 \\
(2.00)\end{array}$ & $\begin{array}{l}0.013 \\
(0.74)\end{array}$ \\
\hline Female & $\begin{array}{l}-0.106 \\
(2.04)\end{array}$ & $\begin{array}{l}0.024 \\
(0.32)\end{array}$ & $\begin{array}{l}-0.087 \\
(1.04)\end{array}$ & $\begin{array}{l}0.119 \\
(1.13)\end{array}$ & $\begin{array}{l}0.107 \\
(0.93)\end{array}$ \\
\hline $\begin{array}{l}\text { Cross } \\
\text { Country/Culture } \\
\text { Contact in Former } \\
\text { Home Country }\end{array}$ & $\begin{array}{l}0.304 \\
(6.31)\end{array}$ & $\begin{array}{r}-0.045 \\
(0.64)\end{array}$ & $\begin{array}{l}0.001 \\
(0.02)\end{array}$ & $\begin{array}{l}0.126 \\
(1.26)\end{array}$ & $\begin{array}{l}0.309 \\
(2.79)\end{array}$ \\
\hline $\begin{array}{l}\text { Previously Visited } \\
\text { Australia }\end{array}$ & $\begin{array}{l}0.494 \\
(3.18)\end{array}$ & $\begin{array}{l}0.313 \\
(1.85)\end{array}$ & $\begin{array}{l}0.166 \\
(0.96)\end{array}$ & $\begin{array}{l}0.329 \\
(2.79)\end{array}$ & $\begin{array}{l}0.593 \\
(2.99)\end{array}$ \\
\hline $\begin{array}{l}\text { Main Reason for } \\
\text { Choosing State } \\
\text { Settled was } \\
\text { Family/Friends }\end{array}$ & $\begin{array}{l}-0.237 \\
(3.34)\end{array}$ & $\begin{array}{l}-0.026 \\
(0.24)\end{array}$ & $\begin{array}{l}-0.065 \\
(0.56)\end{array}$ & $\begin{array}{l}0.032 \\
(0.24)\end{array}$ & $\begin{array}{l}-0.047 \\
(0.31)\end{array}$ \\
\hline $\begin{array}{l}\text { Contact with Ethnic } \\
\text { Agencies }\end{array}$ & $\begin{array}{l}-0.234 \\
(3.32)\end{array}$ & $\begin{array}{l}-0.077 \\
(0.75)\end{array}$ & $\begin{array}{l}0.110 \\
(1.04)\end{array}$ & $\begin{array}{l}0.540 \\
(3.33)\end{array}$ & $\begin{array}{l}0.496 \\
(2.66)\end{array}$ \\
\hline Expect to Stay in & 0.351 & -0.324 & -0.052 & 0.012 & -0.375 \\
\hline
\end{tabular}




\begin{tabular}{|c|c|c|c|c|c|}
\hline Australia & $(3.15)$ & $(1.94)$ & $(2.38)$ & $(0.02)$ & $(1.09)$ \\
\hline $\begin{array}{l}\text { Family Structure } \\
\text { MUS }^{\left({ }^{c}\right)}\end{array}$ & $\begin{array}{l}-0.164 \\
(1.97)\end{array}$ & $\begin{array}{l}-0.050 \\
(0.41)\end{array}$ & $\begin{array}{r}-0.051 \\
(0.38)\end{array}$ & $\begin{array}{l}0.005 \\
(0.03)\end{array}$ & $\begin{array}{r}-0.190 \\
(0.88)\end{array}$ \\
\hline $\mathrm{OS}^{(\mathrm{d})}$ & $\begin{array}{l}-0.056 \\
(0.60)\end{array}$ & $\begin{array}{l}0.095 \\
(0.74)\end{array}$ & $\begin{array}{l}0.190 \\
(1.47)\end{array}$ & $\begin{array}{l}0.347 \\
(1.65)\end{array}$ & $\begin{array}{l}0.005 \\
(0.02)\end{array}$ \\
\hline $\operatorname{KIDS}^{(\mathrm{e})}$ & $\begin{array}{l}-0.120 \\
(2.08)\end{array}$ & $\begin{array}{l}-0.136 \\
(1.67)\end{array}$ & $\begin{array}{l}-0.051 \\
(0.57)\end{array}$ & $\begin{array}{l}-0.253 \\
(2.20)\end{array}$ & $\begin{array}{l}-0.126 \\
(1.09)\end{array}$ \\
\hline $\operatorname{MUR}^{(\mathrm{f})}$ & $\begin{array}{l}0.071 \\
(0.57)\end{array}$ & $\begin{array}{l}-0.256 \\
(1.48)\end{array}$ & $\begin{array}{l}0.226 \\
(1.34)\end{array}$ & $\begin{array}{r}-0.246 \\
(0.98)\end{array}$ & $\begin{array}{l}-0.326 \\
(1.34)\end{array}$ \\
\hline $\mathrm{OR}^{(\mathrm{g})}$ & $\begin{array}{l}-0.285 \\
(2.00)\end{array}$ & $\begin{array}{l}-0.219 \\
(2.01)\end{array}$ & $\begin{array}{l}0.031 \\
(0.20)\end{array}$ & $\begin{array}{l}0.079 \\
(0.72)\end{array}$ & $\begin{array}{l}0.189 \\
(2.08)\end{array}$ \\
\hline \multicolumn{6}{|c|}{ Birthplace (Europe and USSR) } \\
\hline Oceania/Antarctica & $\begin{array}{c}2.362 \\
(10.07)\end{array}$ & $\begin{array}{l}-0.391 \\
(1.10)\end{array}$ & $\begin{array}{l}-0.914 \\
(2.59)\end{array}$ & $\begin{array}{l}-0.871 \\
(2.25)\end{array}$ & $\begin{array}{l}-1.083 \\
(2.41)\end{array}$ \\
\hline $\begin{array}{l}\text { Middle East and } \\
\text { North Africa }\end{array}$ & $\begin{array}{l}0.033 \\
(0.40)\end{array}$ & $\begin{array}{l}0.113 \\
(0.95)\end{array}$ & $\begin{array}{l}0.127 \\
(0.98)\end{array}$ & $\begin{array}{l}-0.146 \\
(0.92)\end{array}$ & $\begin{array}{l}0.011 \\
(0.06)\end{array}$ \\
\hline Southeast Asia & $\begin{array}{l}0.495 \\
(7.16)\end{array}$ & $\begin{array}{l}-0.327 \\
(3.24)\end{array}$ & $\begin{array}{l}-0.544 \\
(1.99)\end{array}$ & $\begin{array}{l}-0.111 \\
(0.75)\end{array}$ & $\begin{array}{l}-0.496 \\
(2.94)\end{array}$ \\
\hline Northeast Asia & $\begin{array}{r}-0.381 \\
(4.88)\end{array}$ & $\begin{array}{l}-0.034 \\
(0.29)\end{array}$ & $\begin{array}{l}-0.201 \\
(1.55)\end{array}$ & $\begin{array}{r}-0.638 \\
(3.98)\end{array}$ & $\begin{array}{l}-0.656 \\
(3.67)\end{array}$ \\
\hline $\begin{array}{l}\text { Southern and } \\
\text { Central Asia }\end{array}$ & $\begin{array}{l}0.807 \\
(8.72)\end{array}$ & $\begin{array}{r}-0.022 \\
(0.16)\end{array}$ & $\begin{array}{l}-0.285 \\
(1.90)\end{array}$ & $\begin{array}{r}-0.040 \\
(0.21)\end{array}$ & $\begin{array}{r}-0.336 \\
(1.53)\end{array}$ \\
\hline $\begin{array}{l}\text { South/Central } \\
\text { America and } \\
\text { Caribbean }\end{array}$ & $\begin{array}{l}-0.380 \\
(2.45)\end{array}$ & $\begin{array}{l}0.027 \\
(0.23)\end{array}$ & $\begin{array}{l}0.152 \\
(0.59)\end{array}$ & $\begin{array}{l}0.225 \\
(0.70)\end{array}$ & $\begin{array}{l}0.201 \\
(0.58)\end{array}$ \\
\hline $\begin{array}{l}\text { Other Africa (Sub- } \\
\text { Saharan Africa) }\end{array}$ & $\begin{array}{l}1.019 \\
(6.77)\end{array}$ & $\begin{array}{l}-0.023 \\
(0.10)\end{array}$ & $\begin{array}{l}-0.164 \\
(0.60)\end{array}$ & $\begin{array}{l}-0.235 \\
(0.90)\end{array}$ & $\begin{array}{r}-0.287 \\
(0.95)\end{array}$ \\
\hline
\end{tabular}

For notes to Table, see Table 7.

There are six features of the Table 9 results.

First, English skills improve with duration of residence in Australia, as reflected in the positive coefficients on the wave shift factors (listed in the row for the constant term). Most of this improvement appears to occur over the initial settlement period, with the difference between wave 3 and wave 2 being statistically insignificant.

Second, the second cohort of immigrants had, on average, greater proficiency in English than the members of the first cohort at arrival in Australia, but less rapid improvement over the interval between the first and second interviews in Australia. Given the way the interaction terms are specified in equation (6), the improvement for the second cohort is given by the difference between the figures in the final two columns. 
Thus, $2.57-1.62=0.95$, which is smaller than 1.21. A negative relationship between initial levels of English skills and subsequent improvements is the typical finding in the literature.

Third, among the first cohort, immigrants who entered Australia under a Humanitarian visa improved their English skills vis-à-vis Independent visaed immigrants with duration of residence in Australia. Relative changes in English skills among the other visa categories with duration of residence in Australia were not significant.

Fourth, the interaction terms for cohort two show that most visa groups in this cohort have English skills that are relatively inferior to the English skills of the Independent visaed groups. Or put another way, relative to the other categories, Independent visaed immigrants in cohort two have more favourable English skills than the same visa group in cohort one. The interaction terms for Skilled-Australian Sponsored immigrants in cohort two are, however, insignificant. This implies that their position relative to that of Independent visaed immigrants remained the same as it was among immigrants in cohort one. It improved, however, relative to the other three classes of immigrants in cohort two compared to cohort one. Thus, the analysis reveals, in cohort two compared to cohort one, a widening of the difference between the English skills of immigrants points-tested and those who were not points-tested for entry into Australia.

Fifth, among the other characteristics included in the model of English proficiency, only three have effects that differ across waves or cohorts. The age at migration variable is consistently associated with negative interaction effects. That is, the older an immigrant at the time of arrival in Australia, the poorer their English language skills and the less likely they are to improve their English skills with duration of residence in Australia. This effect is more pronounced for members of the second cohort than it is for members of the first cohort. The positive impact of having previously visited Australia on English proficiency is more pronounced, and more persistent, for immigrants in the second cohort than it is for immigrants in the first cohort. Finally, the birthplace fixed effects suggest that the European/USSR reference group tends to improve their relative standing with duration of residence in Australia. They also have relatively superior English skills in the second cohort than in the first. 
A sixth finding is the lower reported English language proficiency for women in Cohort 1, Wave 1, which does not diminish with duration of residence in Australia or change in LSIA2.

What do these results mean for the interpretation of the impact of immigration policy on the English speaking skills of immigrants?

The main implication is that between cohorts one and two, the English skills of Independent visaed immigrants have improved markedly. The English skills of the Skilled-Australian Sponsored group have also improved. These are the groups of immigrants directly affected by the changes in the points tests documented earlier. Moreover, in cohort two, the gaps between the English skills of immigrants who are points-test for entry into Australia and other immigrants widen over the first few years in Australia, rather than narrow as is the case for immigrants in cohort one.

Of course, part of these "apparent" policy effects might be associated with individual fixed effects. Whether these should be netted out of the estimates is a moot point, as these might be exactly the factors on which the immigration process is selecting. The importance of the individual fixed effects was examined using a linear probability model.

The results from this approach (presented in Appendix E, available from the authors upon request) show that the apparent improvement in English skills with duration of residence in Australia is reduced, though evidence of marked improvement remains. The estimated differentials in English proficiency associated with visa category are compressed for LSIA1. However, in LSIA2, the control for fixed effects is associated with a compression of the differentials in English proficiency across the points-tested visa across categories, and a widening of the differentials in English proficiency among the non-points-tested visa categories. The control for fixed effects is also associated with a widening of the differential in English proficiency between the points-tested and nonpoints-tested categories in LSIA2, and with a slight diminution in this differential in LSIA1.

A final examination of the effects of immigration policy involved splitting the Independent visaed immigrants in the second cohort into two sub-categories. The first of 
these comprises the post July 1999 visa categories (sub-classes 138 and 139). There immigrants were processed under the more stringent language requirements outlined above. The second comprises all other Independent immigrants, who would have had their immigration applications assessed under the earlier criteria. Estimation of the probit specification of Table 9 reveals, however, no significant differences between the English skills of these two classes of immigrants. In part this might be due to the almost universal English language proficiency of the different groups of Independent immigrants.

Table 10 presents a summary of the findings from this analysis.

Table 10

Quantification of Role of English Language Ability in Immigrant Selection in LSIA1 and LSIA2

Panel A: LSIA1 compared to LSIA2

\begin{tabular}{|c|c|c|c|}
\hline Visa Category & $\begin{array}{c}\text { Differences between } \\
\text { Cohorts Picks Up }\end{array}$ & $\begin{array}{l}\text { Impact on Probit } \\
\text { Index of (2) }\end{array}$ & $\begin{array}{l}\text { Implications of } \\
\text { Impact in (3) }\end{array}$ \\
\hline (1) & (2) & (3) & (4) \\
\hline $\begin{array}{l}\text { Non Points Tested } \\
\text { (Family, } \\
\text { Humanitarian) }\end{array}$ & Cohort effects & $\begin{array}{l}\text { Positive effect of } \\
\text { between } 0.609 \text { and } \\
1.203\end{array}$ & $\begin{array}{l}\text { Cohort effects give } \\
\text { improvement in } \\
\text { English skills }\end{array}$ \\
\hline Independent & $\begin{array}{l}\text { Impact of changes in } \\
\text { ORE list + cohort } \\
\text { effects }\end{array}$ & $\begin{array}{l}\text { Positive effect of } \\
1.625\end{array}$ & $\begin{array}{l}\text { Both cohort effects } \\
\text { and changes in ORE } \\
\text { are associated with } \\
\text { improvements in } \\
\text { English skills }\end{array}$ \\
\hline $\begin{array}{l}\text { Skilled-Australian } \\
\text { Sponsored }\end{array}$ & $\begin{array}{l}\text { Impact of points for } \\
\text { English ability }+ \\
\text { impact of change in } \\
\text { ORE list }+ \text { cohort } \\
\text { effects }\end{array}$ & $\begin{array}{l}\text { Positive effect of } \\
1.795 \text { on probit index }\end{array}$ & $\begin{array}{l}\text { Points for English } \\
\text { ability as well as } \\
\text { cohort effects and } \\
\text { changes in ORE } \\
\text { associated with } \\
\text { improvement in } \\
\text { English skills }\end{array}$ \\
\hline \multicolumn{4}{|c|}{ Panel B: Pre- and Post-July 1999 LSIA2 } \\
\hline Visa Category & $\begin{array}{l}\text { Difference between } \\
\text { pre- and post July } \\
1999 \text { Cohorts }\end{array}$ & $\begin{array}{l}\text { Impact on Probit } \\
\text { Index of (2) }\end{array}$ & $\begin{array}{l}\text { Implications of } \\
\text { Impact in (3) }\end{array}$ \\
\hline (1) & (2) & (3) & (4) \\
\hline Independent & $\begin{array}{l}\text { Impact of minimum } \\
\text { English threshold }\end{array}$ & $\begin{array}{l}\text { Minimal, if any } \\
\text { impact }\end{array}$ & $\begin{array}{l}\text { Change not of any } \\
\text { consequence }\end{array}$ \\
\hline
\end{tabular}

Note: (a) From the column headed $\varphi_{1}$ LSIA2 $_{i} X_{i}$ in Table 9. 
Table 10 indicates that cohort effects have substantial positive effects on English language skills in this analysis. A "difference between differences" approach can be applied to the findings in Table 10 to assess the impact of changes to the Occupations Requiring English list, and of the introduction of points for English skills among the Skilled-Australian sponsored immigrants.

Comparison of the second and first rows of Table 10 (i.e., Independent versus non-points tested immigrants) reveals the impact of changes to the list of Occupations Requiring English. This is positive, and quantitatively as important as the cohort effects given in the first row of the table. Comparison of the third and second rows (i.e., SkilledAustralian Sponsored versus Independent immigrants) reveals the impact of the introduction of points for English skills among the Skilled-Australian Sponsored immigrants. This is shown to be positive, but quite minor. Nevertheless, the conclusion that needs to be drawn from this analysis is that immigration policy can affect immigrants' language skills.

Finally, the determinants of English speaking proficiency among Migrating Unit Spouses were examined. These spouses need to be assigned the same visa category as the Principal Applicant. In addition, several other variables, for example, the main reason for choosing state settled being family or friends, and whether there had been post-arrival contact with ethnic agencies, were not available for the Migrating Unit Spouses. In these cases information provided by the Principal Applicant is used.

The general patterns in the results for Migrating Unit Spouses are similar to those described above for Principal Applicants, and only brief comments on the links between English speaking skills and visa categories are provided here. Further analysis is provided in Appendix F.

The ranking of English-speaking skills across visa categories for Migrating Unit Spouses is the same as it is for Principal Applicants, although the language skills of the two points-tested categories (Independent and Skilled-Australian Sponsored) do not differ significantly in the case of Migrating Unit Spouses. The similarity in the ranking for Principal Applicants and their Migrating Unit Spouses presumably comes about through assortive mating and the complementarities of the post-migration learning of 
English among family members that has been emphasised by Chiswick, Lee and Miller (2004b).

The differences in the English language proficiency across visa categories among the first cohort of Migrating Unit Spouses do not vary with duration in Australia. Nonpoints tested immigrants (Humanitarian, Family) among the second cohort have relatively more limited English speaking skills than was the case among the first cohort. The superior English skills of the spouses of points-tested immigrants imply a double advantage to an immigration policy that favours Principal Applicants with superior English language skills.

\section{Summary and Conclusion}

Immigrants' language skills are important for understanding the determinants of their economic well-being. The analyses above provide an account of the dynamics of the processes through which immigrants acquire the English language skills that have been shown in previous research (see Chiswick and Miller (1995) and the references therein) to be of fundamental importance to their economic well-being. It does this by exploiting several features of the Longitudinal Survey of Immigrants to Australia (LSIA). First, in this survey, unlike Census data, the visa classes of the immigrants are known. Second, information is available for two cohorts of immigrants: the first representative of arrivals between 1993 and 1995; the second representative of arrivals between 1999 and 2000. The first panel was followed for 3.5 years after arrival and the second for 1.5 years. The changes in the role of English language skills in immigrant selection affected some visa classes, but not others, over this time period. This permits an assessment of the effect of immigrant selection policy on the English language skills of immigrants.

There are clear differences across visa classes in the English language skills of immigrants at the time of arrival. Specifically, immigrants who entered Australia under points-tested visa categories (Independent and Skilled-Australian Sponsored) have English-language skills superior to the skills of immigrants in the non-points-tested categories (Family and Humanitarian based visas). Humanitarian visaed immigrants have quite limited English skills at arrival. The English skills of all immigrants improve with 
time spent in Australia, with the most rapid improvement being experienced by the visa groups with the poorest skills at arrival.

The English skills of immigrants in the second arrival cohort (1999-2000) are, in general, superior to those in the first arrival cohort, with the differences being greater for immigrants in the points-tested category. It was in the latter category that there was an increase in the English language requirements for a visa.

These broad patterns are evident in both cross-tabulations (Tables 4 and 6) and in the multivariate statistical analyses that follow a standard cross-sectional approach (Table 7). The statistical analyses also identify a set of variables that influence the English language skills of immigrants: age at migration (negative influence), educational attainment (positive influence), being a female (negative influence), having crosscountry/culture contact in the former home country (positive influence), having previously visited Australia (positive influence), the presence of family and friends as the main factor influencing location decisions (negative influence), an expectation of staying in Australia (positive influence), duration of residence in Australia (positive influence) and living with other family member (negative influence).

The detailed statistical analyses that exploited the longitudinal dimension of the data set (Table 9) employed a difference between differences approach that enables the impact of immigrant selection policy to be quantified. This showed that the various expansions to the list of Occupations Requiring English have had a marked impact on the English language skills of points-tested immigrants. It also revealed that the introduction of points for English skills among the Skilled-Australian Sponsored Immigrants in 1997 was relatively minor.

Thus, it is readily apparent that immigration policy can affect immigrants' language skills, and hence both their initial economic success in Australia and the speed of their subsequent adjustment. This effect occurs both directly, in terms of the higher levels of proficiency among Principal Applicants, and indirectly, via the superior language skills of the spouses of points-tested immigrants. Given the positive links between the English skills of parents and children documented in Chiswick, Lee and Miller (2005), the overall effect of these government policy changes will be more favorable than documented here. Having a minimum threshold such as in the 
Occupations Requiring English list, or the core criteria of the July 1999 reforms, appears to be a more effective policy instrument than simply having points for English as one of a number of attributes that attracts points. Perhaps this is the major lesson that other governments could learn from Australia's "natural experiments" reported on here. 


\section{REFERENCES}

Chiswick, Barry R. (1979). "The Economic Progress of Immigrants: Some Apparently Universal Patterns", pp. 357-399 in William Fellner (ed.), Contemporary Economic Problems 1979, American Enterprise Institute for Public Policy Research, Washington, D.C..

Chiswick, Barry R., Yew Liang Lee and Paul W. Miller (2003). "Immigrants' Language Skills: The Australian Experience in A Longitudinal Survey", Annales d'Economie et de Statistique, Vol. 71-72, pp. 97-139.

Chiswick, Barry R., Yew Liang Lee and Paul W. Miller (2004a). “Immigrants' Language Skills and Visa Category", International Migration Review, (forthcoming).

Chiswick, Barry R., Yew Liang Lee and Paul W. Miller (2004b). "Family Matters: The Role of the Family in Immigrants' Destination Language Acquisition", Journal of Population Economics, (forthcoming).

Chiswick, Barry R., Yew Liang Lee and Paul W. Miller (2005) "Parents and Children Talk: The Family Dynamics of English Language Proficiency", photocopied, Business School, The University of Western Australia.

Chiswick, Barry R. and Paul W. Miller (1992). "Language in the Immigrant Labor Market”, pp. 229-296 and pp. 471-476 in Barry R. Chiswick (ed.), Immigration, Language and Ethnicity: Canada and the United States, American Enterprise Institute, Washington D.C.

Chiswick, Barry R. and Paul W. Miller (1995). "The Endogeneity Between Language and Earnings: International Analyses," Journal of Labor Economics, Vol.13, No.2, April, pp. 246-288.

Chiswick, Barry R. and Paul W. Miller (1996). "Ethnic Networks and Language Proficiency Among Immigrants", Journal of Population Economics, Vol. 9, pp. 19-35.

Chiswick, Barry R. and Paul W. Miller (1998a). "English Language Fluency Among Immigrants in the United States", Research in Labor Economics, JAI Press, Vol. 17, 1998, pp.151-200.

Chiswick, Barry R. and Paul W. Miller (1998b). "Language Skill Definition: A Study of Legalized Aliens", International Migration Review, Vol. 32, No. 4, pp. 877-900.

Chiswick, Barry R. and Paul W. Miller (1999). "Immigration, Language and Multiculturalism in Australia", Australian Economic Review, Vol. 32, No. 4, pp. 369-385. 
Chiswick, Barry R. and Paul W. Miller (2004). "Linguistic Distance: A Quantitative Measure of the Distance Between English and Other Languages", Journal of Multilingual and Multicultural Development, (forthcoming).

Department of Immigration and Multicultural Affairs (DIMA) (1997). Australian Immigration: Consolidated Statistics, No. 19, 1995-1996, Canberra: DIMA.

Department of Immigration and Multicultural Affairs (1999). Review of the Independent and Skilled-Australian Linked Categories, Commonwealth of Australia, Canberra.

Kan, Arnold (1991). The Australian Experience of Skilled Migration, Bureau of Immigration Research, Australian Government Publishing Service, Canberra.

Kominski, Robert (1989). "How Good is 'How Well'? An Examination of the Census English-Speaking Ability Question”, American Statistical Association 1989 Proceedings of the Social Statistics Section, pp. 333-338.

Long, Michael H. (1990). "Maturational Constraints on Language Development", Studies in Second Language Acquisition, Vol. 12, No. 3, pp. 251-285.

Richardson, Sue, Frances Robertson and Diana Ilsley (2001). The Labor Force Experience of New Immigrants, Info Products, Canberra.

SAS Institute Inc., (1994). SAS/STAT User's Guide, Version 6, Vol. 2, $4^{\text {th }}$ Edn., SAS Institute Inc., United States of America.

Service, Elisabet and Fergus I.M. Craik (1993). "Differences Between Young and Older Adults in Learning a Foreign Vocabulary", Journal of Memory and Language, Vol. 32, pp. 608-623. 


\section{APPENDIX A}

Table A.1

Pass Marks for Independent and Skilled-Australian Sponsored Immigration Categories, 1989-1998

\begin{tabular}{|l|c|c|}
\hline Effective Date & Independent & $\begin{array}{c}\text { Skilled-Australian } \\
\text { Sponsored }\end{array}$ \\
\hline December 19 1989 & 100 & 85 \\
\hline May 16 1990 & 95 & 85 \\
\hline January 8 1992 & 100 & 90 \\
\hline February 15 1992 & 110 & 100 \\
\hline December 23 1993 & 100 & 95 \\
\hline December 1 1995 & 110 & 95 \\
\hline August 1 1996 & 115 & 95 \\
\hline November 1 1996 & 115 & 115 \\
\hline March 3 1998 & 110 & 115 \\
\hline
\end{tabular}




\section{APPENDIX B}

\section{Table B.1}

\section{English-Language Reading Skills by Gender and Visa Category, Non-English Speaking Background Immigrants Arriving in Australia 1993-1995 and 1999-2000}

\section{Males}

\begin{tabular}{|l|c|c|c|c|c|c|}
\hline & English & \multicolumn{2}{|c|}{ English is not the Only or Best Spoken Language , } & \\
& $\begin{array}{l}\text { Only or } \\
\text { English }\end{array}$ & \multicolumn{4}{|c|}{} \\
\cline { 2 - 6 } Visa Category & Best & Very Well & Well & Not Well & Not at All & \multirow{2}{*}{ Total } \\
\hline Independent & 23.46 & 42.14 & 29.45 & 4.79 & 0.16 & 100.00 \\
& $\mathbf{3 3 . 8 0}$ & $\mathbf{5 7 . 1 0}$ & $\mathbf{9 . 1 0}$ & $\mathbf{0 . 0 0}$ & $\mathbf{0 . 0 0}$ & $\mathbf{1 0 0 . 0 0}$ \\
\hline Skilled-Aust & 18.73 & 33.27 & 26.82 & 15.71 & 5.47 & 100.00 \\
Sponsored & $\mathbf{3 5 . 5 4}$ & $\mathbf{3 6 . 0 6}$ & $\mathbf{2 1 . 4 8}$ & $\mathbf{5 . 4 5}$ & $\mathbf{1 . 4 8}$ & $\mathbf{1 0 0 . 0 0}$ \\
\hline Business/Employer & 19.08 & 26.95 & 29.37 & 16.87 & 7.73 & 100.00 \\
Nomination & $\mathbf{2 6 . 1 4}$ & $\mathbf{2 1 . 7 7}$ & $\mathbf{3 3 . 0 8}$ & $\mathbf{1 4 . 1 7}$ & $\mathbf{4 . 8 5}$ & $\mathbf{1 0 0 . 0 0}$ \\
\hline Family & 14.48 & 21.36 & 29.39 & 22.86 & 11.91 & 100.00 \\
& $\mathbf{1 2 . 2 9}$ & $\mathbf{1 9 . 4 5}$ & $\mathbf{2 8 . 7 9}$ & $\mathbf{2 3 . 3 2}$ & $\mathbf{1 6 . 1 4}$ & $\mathbf{1 0 0 . 0 0}$ \\
\hline Humanitarian & 0.42 & 9.01 & 28.88 & 38.55 & 23.13 & 100.00 \\
& $\mathbf{1 . 6 9}$ & $\mathbf{8 . 7 8}$ & $\mathbf{2 6 . 8 1}$ & $\mathbf{4 0 . 1 7}$ & $\mathbf{2 2 . 5 6}$ & $\mathbf{1 0 0 . 0 0}$ \\
\hline Migrating Unit & 11.97 & 20.53 & 24.22 & 22.94 & 20.33 & 100.00 \\
Spouse & $\mathbf{2 4 . 2 6}$ & $\mathbf{2 3 . 5 2}$ & $\mathbf{2 4 . 5 2}$ & $\mathbf{1 8 . 9 3}$ & $\mathbf{8 . 7 7}$ & $\mathbf{1 0 0 . 0 0}$ \\
\hline
\end{tabular}

\section{Females}

\begin{tabular}{|c|c|c|c|c|c|c|}
\hline \multirow[b]{2}{*}{ Visa Category } & \multirow{2}{*}{$\begin{array}{l}\text { English } \\
\text { Only or } \\
\text { English } \\
\text { Best }\end{array}$} & \multicolumn{4}{|c|}{$\begin{array}{c}\text { English is not the Only or Best Spoken Language, } \\
\text { Speaks English: }\end{array}$} & \multirow[b]{2}{*}{ Total } \\
\hline & & Very Well & Well & Not Well & Not at All & \\
\hline \multirow[t]{2}{*}{ Independent } & 17.51 & 57.10 & 23.57 & 1.83 & 0.00 & 100.00 \\
\hline & 40.17 & 42.92 & 15.71 & 1.20 & 0.00 & 100.00 \\
\hline \multirow{2}{*}{$\begin{array}{l}\text { Skilled-Aust } \\
\text { Sponsored }\end{array}$} & 24.84 & 36.26 & 27.56 & 9.13 & 2.20 & 100.00 \\
\hline & 39.04 & 37.79 & 12.53 & 10.65 & $\mathbf{0 . 0 0}$ & 100.00 \\
\hline \multirow{2}{*}{$\begin{array}{l}\text { Business/Employer } \\
\text { Nomination }\end{array}$} & 18.05 & 32.63 & 25.50 & 10.42 & 13.40 & 100.00 \\
\hline & 9.29 & 23.43 & 26.97 & 35.04 & 5.27 & 100.00 \\
\hline \multirow[t]{2}{*}{ Family } & 9.74 & 20.82 & 26.31 & 21.82 & 21.33 & 100.00 \\
\hline & 12.39 & 20.76 & 26.54 & 27.11 & 13.20 & 100.00 \\
\hline \multirow[t]{2}{*}{ Humanitarian } & 0.79 & 5.29 & 21.96 & 30.06 & 41.89 & 100.00 \\
\hline & 0.11 & 5.37 & 26.86 & 38.39 & 29.27 & 100.00 \\
\hline \multirow{2}{*}{$\begin{array}{l}\text { Migrating Unit } \\
\text { Spouse }\end{array}$} & 11.67 & 16.50 & 26.92 & 23.76 & 21.15 & 100.00 \\
\hline & 19.95 & 18.70 & 26.99 & 22.69 & 11.67 & 100.00 \\
\hline
\end{tabular}

Notes: Figures in normal type are for immigrants arriving in 1993-1995, six months after arrival; Figures in bold type are for immigrants arriving in 1999-2000, six months after arrival.

Data exclude persons born in the English speaking developed countries (New Zealand, UK, US and

Canada)

Row totals may not sum to 100.0 due to rounding.

Sample Sizes: Cohort 1: 2,463 male PAs, weighted sample of 29,547, 285 male MUSs, weighted sample of 2,842; 2,007 female PAs, weighted sample of 29,653, 1,117 female MUSs, weighted sample of 12,349.

Cohort 2: 1,369 male PAs, weighted sample of 12,261, 199 male MUSs, weighted sample of 1,723. 1,240

female PAs, weighted sample of 12,874, 649 female MUSs, weighted sample of 5,344. 
Table B.2

\section{English-Language Writing Skills by Gender and Visa Category, Non-English Speaking Background Immigrants Arriving in Australia 1993-1995 and 1999-2000}

\section{Males}

\begin{tabular}{|l|c|c|c|c|c|c|}
\hline & \multirow{2}{*}{$\begin{array}{l}\text { English } \\
\text { Only or } \\
\text { English }\end{array}$} & \multicolumn{2}{|c|}{ English is not the Only or Best Spoken Language, } & \\
\cline { 2 - 6 } Visa Category & Best & Very Well & Well & Not Well & Not at All & \multirow{2}{*}{ Total } \\
\hline Independent & 23.46 & 31.53 & 34.71 & 9.88 & 0.41 & 100.00 \\
& $\mathbf{3 3 . 8 0}$ & $\mathbf{4 0 . 1 1}$ & $\mathbf{2 4 . 1 1}$ & $\mathbf{1 . 9 8}$ & $\mathbf{0 . 0 0}$ & $\mathbf{1 0 0 . 0 0}$ \\
\hline Skilled-Aust & 18.73 & 20.83 & 31.21 & 21.51 & 7.72 & 100.00 \\
Sponsored & $\mathbf{3 5 . 5 4}$ & $\mathbf{2 5 . 6 6}$ & $\mathbf{2 8 . 1 8}$ & $\mathbf{8 . 6 8}$ & $\mathbf{1 . 9 3}$ & $\mathbf{1 0 0 . 0 0}$ \\
\hline Business/Employer & 19.08 & 22.06 & 24.24 & 26.04 & 8.58 & 100.00 \\
Nomination & $\mathbf{2 6 . 1 4}$ & $\mathbf{1 6 . 6 4}$ & $\mathbf{3 1 . 2 9}$ & $\mathbf{2 0 . 1 3}$ & $\mathbf{5 . 8 0}$ & $\mathbf{1 0 0 . 0 0}$ \\
\hline Family & 14.48 & 13.27 & 28.23 & 28.92 & 15.09 & 100.00 \\
& $\mathbf{1 2 . 2 9}$ & $\mathbf{1 2 . 5 3}$ & $\mathbf{2 5 . 8 0}$ & $\mathbf{2 7 . 2 0}$ & $\mathbf{2 2 . 1 8}$ & $\mathbf{1 0 0 . 0 0}$ \\
\hline Humanitarian & 0.42 & 5.37 & 21.42 & 46.66 & 26.12 & 100.00 \\
& $\mathbf{1 . 6 9}$ & $\mathbf{5 . 5 0}$ & $\mathbf{2 0 . 4 7}$ & $\mathbf{4 4 . 9 2}$ & $\mathbf{2 7 . 4 2}$ & $\mathbf{1 0 0 . 0 0}$ \\
\hline Migrating Unit & 11.97 & 12.04 & 26.69 & 26.58 & 22.72 & 100.00 \\
Spouse & $\mathbf{2 4 . 2 6}$ & $\mathbf{1 9 . 5 2}$ & $\mathbf{1 9 . 9 2}$ & $\mathbf{2 2 . 9 7}$ & $\mathbf{1 3 . 3 4}$ & $\mathbf{1 0 0 . 0 0}$ \\
\hline
\end{tabular}

\section{Females}

\begin{tabular}{|l|c|c|c|c|c|c|}
\hline & \multirow{2}{*}{$\begin{array}{l}\text { English } \\
\text { Only or } \\
\text { English }\end{array}$} & \multicolumn{2}{|c|}{ English is not the Only or Best Spoken Language, } & \\
\cline { 2 - 6 } Visa Category & Best & Very Well & Well & Not Well & Not at All & Total \\
\cline { 2 - 6 } Independent & 17.51 & 38.94 & 39.87 & 3.69 & 0.00 & 100.00 \\
& $\mathbf{4 0 . 1 7}$ & $\mathbf{3 2 . 0 3}$ & $\mathbf{2 3 . 5 6}$ & $\mathbf{4 . 2 3}$ & $\mathbf{0 . 0 0}$ & $\mathbf{1 0 0 . 0 0}$ \\
\hline Skilled-Aust & 24.84 & 26.70 & 30.24 & 15.83 & 2.40 & 100.00 \\
Sponsored & $\mathbf{3 9 . 0 4}$ & $\mathbf{2 8 . 6 5}$ & $\mathbf{2 0 . 3 5}$ & $\mathbf{1 1 . 9 6}$ & $\mathbf{0 . 0 0}$ & $\mathbf{1 0 0 . 0 0}$ \\
\hline Business/Employer & 18.05 & 27.49 & 25.78 & 17.86 & 10.83 & 100.00 \\
Nomination & $\mathbf{9 . 2 9}$ & $\mathbf{1 3 . 8 2}$ & $\mathbf{3 2 . 3 0}$ & $\mathbf{3 3 . 1 4}$ & $\mathbf{1 1 . 4 4}$ & $\mathbf{1 0 0 . 0 0}$ \\
\hline Family & 9.74 & 12.74 & 29.11 & 25.98 & 22.42 & 100.00 \\
& $\mathbf{1 2 . 3 9}$ & $\mathbf{1 4 . 0 5}$ & $\mathbf{2 5 . 9 9}$ & $\mathbf{3 4 . 0 3}$ & $\mathbf{1 3 . 5 4}$ & $\mathbf{1 0 0 . 0 0}$ \\
\hline Humanitarian & 0.79 & 2.65 & 14.93 & 36.28 & 45.34 & 100.00 \\
& $\mathbf{0 . 1 1}$ & $\mathbf{3 . 3 3}$ & $\mathbf{2 2 . 8 0}$ & $\mathbf{4 0 . 5 4}$ & $\mathbf{3 3 . 2 1}$ & $\mathbf{1 0 0 . 0 0}$ \\
\hline Migrating Unit & 11.67 & 8.73 & 29.26 & 27.55 & 22.79 & 100.00 \\
Spouse & $\mathbf{1 9 . 9 5}$ & $\mathbf{1 3 . 4 1}$ & $\mathbf{2 5 . 2 6}$ & $\mathbf{2 8 . 1 5}$ & $\mathbf{1 3 . 2 3}$ & $\mathbf{1 0 0 . 0 0}$ \\
\hline
\end{tabular}

Notes: Figures in normal type are for immigrants arriving in 1993-1995, six months after arrival; Figures in bold type are for immigrants arriving in 1999-2000, six months after arrival.

Data exclude persons born in the English speaking developed countries (New Zealand, UK, US and Canada)

Row totals may not sum to 100.0 due to rounding.

Sample Sizes: Cohort 1: 2,463 male PAs, weighted sample of 29,547, 285 male MUSs, weighted sample of 2,842; 2,007 female PAs, weighted sample of 29,653, 1,117 female MUSs, weighted sample of 12,349.

Cohort 2: 1,369 male PAs, weighted sample of 12,261, 199 male MUSs, weighted sample of 1,723. 1,240 female PAs, weighted sample of 12,874, 649 female MUSs, weighted sample of 5,344. 


\section{APPENDIX C: DEFINITIONS OF VARIABLES}

The variables used in the statistical analysis are described below. For the statistical analyses, the relevant population is immigrants aged 15-64 years at arrival, excluding those from the main English-speaking developed countries.

\section{Dependent Variables:}

English Speaking Skills: Five levels of English speaking skills are distinguished. They are: (i) English best (or English only); Speaks a language other than English best and speaks English: (ii) Very well; (iii) Well; (iv) Not well; (v) Not at all. In some analyses the first three categories (denoted "proficient") are distinguished from the remaining categories (denoted "not proficient").

English Reading Skills: Five levels of English reading skills are distinguished. They are: (i) English best (or English only); Speaks a language other than English best and reads English: (ii) Very well; (iii) Well; (iv) Not well; (v) Not at all, or does not speak English at all. ${ }^{31}$ In some analyses the first three categories (denoted "proficient") are distinguished from the remaining categories (denoted "not proficient").

English Writing Skills: Five levels of English writing skills are distinguished. They are: (i) English best (or English only); Speaks a language other than English best and writes English: (ii) Very well; (iii) Well; (iv) Not well; (v) Not at all, or does not speak English at all. $^{32}$ In some analyses the first three categories (denoted "proficient") are distinguished from the remaining categories (denoted "not proficient").

\section{Independent Variables:}

Age at migration: This is a continuous variable that measures the individual's age at migration. The analyses are restricted to immigrants aged 15 to 64 years at the time of migration.

Educational Attainment: The continuous "Years of Education" variable was created by assigning years of full-time equivalent education to each of the nine levels of education available. They are: (i) Higher degree (19.5 years); (ii) Postgraduate diploma (17.5 years); (iii) Bachelor degree (16.5 years); (iv) Technical/professional qualification (15 years); (v) Trade (13 years) ; (vi) 12 or more years of schooling (13 years); (vii) 10-11 years (10.5 years); (viii) 7-9 years (8 years); and (ix) 6 years or less (6 years).

\footnotetext{
${ }^{31}$ Information on English reading and writing skills was not collected in the first two waves for cohort 1 where the individual could not speak English at all. It is assumed that these individuals would not be able to read or write English. The data from LSIA2 show that nine percent of the relatively small number who could not speak English at all had some (albeit poor) reading skills, and five percent had some (again, predominantly "Not well") writing skills.

${ }^{32}$ Information on English writing skills was not collected in the first two waves for cohort 1 where the individual could not speak English at all. It is assumed that these individuals would not be able to write in English.
} 
Gender: Dichotomous variable equal to unity if female.

Birthplace: Eight birthplace regions are distinguished, namely: Europe and USSR; Oceania/Antarctica; Middle East and North Africa; Southeast Asia; Northeast Asia; Southern and Central Asia; South/Central America and the Caribbean; Other Africa (SubSaharan Africa)/

Culture/Country Contact: Dichotomous variable equal to unity if the immigrant had cross culture/country contact in their former home country.

Visit to Australia: Dichotomous variable equal to unity for those from migrating units where the PA visited Australia prior to migrating.

Reason for Choice of State Settled: Dichotomous variable equal to unity when family and friends were the main reason for choosing the initial State/Territory settled.

Ethnic Agencies Contact: Dichotomous variable equal to unity when the recent arrival had post-immigrant contact with an ethnic organisation, religious organisation, or voluntary welfare agency.

Emigration: Dichotomous variable equal to unity for PAs who expect to return to their former home country or to emigrate to another country.

Visa Group: Five visa groups are identified in the analysis, and dichotomous variables are used to represent membership of these. They are: (i) Family; (ii) Skilled-Australian Sponsored; (iii) Business Skills and Employer Nomination; (iv) Independent; and (v) Humanitarian. The benchmark group in the regression analysis is Independent. The Family category provides for the entry of spouses, fiancés, unmarried dependent children, children for adoption or adopted by Australians while overseas, parents meeting the "balance of family" test, as well as aged dependent, "last remaining", "special need" and orphan child relatives. There is no points test for this category. The Skilled-Australian

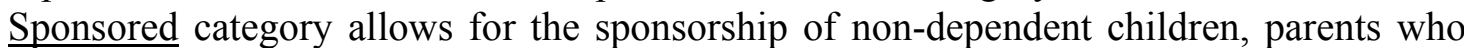
do not meet the "balance of family" test, siblings, and nieces and nephews. A points test is applied to this category based mainly on the job-related skills (particularly qualifications), age and English-language proficiency of the applicant. Business Skills aims to attract people with successful careers in business and who have a genuine and realistic commitment to establishing new businesses or actively participating in existing businesses that will benefit Australia. Applicants are subject to a points test which assess them against their business backgrounds, achievements and skills. The Employer Nomination Scheme is designed to enable Australian employers who are unable to fill vacancies within the Australian labor market or through their own training efforts to recruit skilled workers from overseas. During 1993-95 approximately equal numbers of settlers entered Australian under the Business Skills and Employer Nomination streams (see DIMA (1997)). The Independent category emphasises the selection of young, skilled, employable people through a points test based on skill (qualifications and work 
experience), age, and English proficiency. The Humanitarian program is a flexible program designed to respond to changing international situations. It consists of 3 main categories: Refugee, for those determined as refugees under the United Nations Convention; Special Humanitarian Program for those who suffer severe discrimination amounting to gross violation of human rights; and Special Assistance Category for those who have close links with Australia and who are in situations of discrimination, displacement or hardship. During 1993-95 Refugees comprised around 30 percent, those entering under the Special Humanitarian Program around 25 percent and settlers in the Special Assistance category about 45 percent of the total Humanitarian program (DIMA (1997)).

Family Structure: In the specification where dichotomous variables are used, five variables relating to family structure are distinguished. They are unity: (i) if a spouse who was part of the migrating unit is present in the household (MUS); (ii) if a spouse who was not part of the migrating unit is present in the household (OS); (iii) if there are children in the household (KIDS); (iv) if other relatives who gained approval to migrate to Australia as part of the Principal Applicant's migration application are present in the household (MUR); and (v) if other relatives are present in the household (OR).

Weeks in Australia: This is computed as from information on the date of arrival and the data of interview. 


\section{APPENDIX D}

Longitudinal Models of English Speaking Skills, 15-64 Year Old Males and Females from Non-English Speaking Countries

Table D.1

Linear Probability (OLS) Model of English Speaking Skills, 15-64 Year Old Males and Females from Non-English Speaking Countries

\begin{tabular}{|c|c|c|c|c|c|}
\hline \multirow[b]{2}{*}{ Variable $\left(X_{i}\right)$} & \multicolumn{3}{|c|}{ Cohort 1} & \multicolumn{2}{|c|}{ Cohort 2} \\
\hline & $\beta_{1} X_{i}$ & $\delta_{2} W 2_{i} X_{i}$ & $\delta_{3} W 3_{i} X_{i}$ & $\varphi_{1} \operatorname{LSIA}_{i} X_{i}$ & $\varphi_{2}{ }^{L S I A 2}{ }_{i} W 2_{i} X_{i}$ \\
\hline $\begin{array}{l}\text { Constant/wave/cohort } \\
\text { effects }\end{array}$ & $\begin{array}{l}-0.060 \\
(1.16)\end{array}$ & $\begin{array}{l}0.269 \\
(3.55)\end{array}$ & $\begin{array}{l}0.392 \\
(4.73)\end{array}$ & $\begin{array}{l}0.180 \\
(0.85)\end{array}$ & $\begin{array}{l}0.349 \\
(3.19)\end{array}$ \\
\hline \multicolumn{6}{|c|}{ Visa Category (Independent) } \\
\hline $\begin{array}{l}\text { Humanitarian } \\
\text { (Refugee) }\end{array}$ & $\begin{array}{l}-0.359 \\
(15.29)\end{array}$ & $\begin{array}{l}0.185 \\
(5.39)\end{array}$ & $\begin{array}{l}0.261 \\
(7.22)\end{array}$ & $\begin{array}{l}0.013 \\
(0.27)\end{array}$ & $\begin{array}{l}0.127 \\
(2.50)\end{array}$ \\
\hline Family & $\begin{array}{l}-0.205 \\
(7.62)\end{array}$ & $\begin{array}{l}0.080 \\
(2.12)\end{array}$ & $\begin{array}{l}0.125 \\
(3.32)\end{array}$ & $\begin{array}{l}-0.084 \\
(1.62)\end{array}$ & $\begin{array}{l}0.015 \\
(0.30)\end{array}$ \\
\hline $\begin{array}{l}\text { Skilled-Australian } \\
\text { Sponsored }\end{array}$ & $\begin{array}{l}-0.117 \\
(4.61)\end{array}$ & $\begin{array}{l}0.063 \\
(1.72)\end{array}$ & $\begin{array}{l}0.111 \\
(2.89)\end{array}$ & $\begin{array}{l}0.102 \\
(2.40)\end{array}$ & $\begin{array}{l}0.126 \\
(2.83)\end{array}$ \\
\hline $\begin{array}{l}\text { Business } \\
\text { Skills/ENS }\end{array}$ & $\begin{array}{l}-0.206 \\
(5.54)\end{array}$ & $\begin{array}{l}0.063 \\
(1.15)\end{array}$ & $\begin{array}{l}0.093 \\
(1.61)\end{array}$ & $\begin{array}{l}0.032 \\
(0.56)\end{array}$ & $\begin{array}{l}0.100 \\
(1.64)\end{array}$ \\
\hline Age at Migration & $\begin{array}{l}-0.001 \\
(2.21)\end{array}$ & $\begin{array}{l}-0.004 \\
(3.57)\end{array}$ & $\begin{array}{l}-0.007 \\
(7.13)\end{array}$ & $\begin{array}{l}-0.004 \\
(2.89)\end{array}$ & $\begin{array}{l}-0.006 \\
(4.17)\end{array}$ \\
\hline Education & $\begin{array}{c}0.050 \\
(26.96)\end{array}$ & $\begin{array}{l}0.002 \\
(0.64)\end{array}$ & $\begin{array}{l}0.005 \\
(1.90)\end{array}$ & $\begin{array}{l}-0.011 \\
(3.10)\end{array}$ & $\begin{array}{l}-0.002 \\
(0.55)\end{array}$ \\
\hline Female & $\begin{array}{l}-0.031 \\
(2.48)\end{array}$ & $\begin{array}{l}-0.003 \\
(0.17)\end{array}$ & $\begin{array}{l}-0.025 \\
(1.30)\end{array}$ & $\begin{array}{l}0.033 \\
(1.44)\end{array}$ & $\begin{array}{l}0.010 \\
(0.43)\end{array}$ \\
\hline $\begin{array}{l}\text { Cross } \\
\text { Country/Culture } \\
\text { Contact in Former } \\
\text { Home Country }\end{array}$ & $\begin{array}{l}0.083 \\
(6.96)\end{array}$ & $\begin{array}{l}-0.014 \\
(0.81)\end{array}$ & $\begin{array}{l}-0.006 \\
(0.31)\end{array}$ & $\begin{array}{l}0.019 \\
(0.84)\end{array}$ & $\begin{array}{l}0.044 \\
(1.80)\end{array}$ \\
\hline $\begin{array}{l}\text { Previously Visited } \\
\text { Australia }\end{array}$ & $\begin{array}{l}0.190 \\
(5.61)\end{array}$ & $\begin{array}{l}-0.006 \\
(0.16)\end{array}$ & $\begin{array}{l}-0.056 \\
(1.49)\end{array}$ & $\begin{array}{l}0.022 \\
(0.89)\end{array}$ & $\begin{array}{l}-0.014 \\
(0.35)\end{array}$ \\
\hline $\begin{array}{l}\text { Main Reason for } \\
\text { Choosing State } \\
\text { Settled was } \\
\text { Family/Friends }\end{array}$ & $\begin{array}{r}-0.042 \\
(2.60)\end{array}$ & $\begin{array}{l}-0.007 \\
(0.28)\end{array}$ & $\begin{array}{l}-0.016 \\
(0.62)\end{array}$ & $\begin{array}{l}0.010 \\
(0.35)\end{array}$ & $\begin{array}{l}0.017 \\
(0.57)\end{array}$ \\
\hline $\begin{array}{l}\text { Contact with Ethnic } \\
\text { Agencies }\end{array}$ & $\begin{array}{l}-0.059 \\
(3.44)\end{array}$ & $\begin{array}{l}0.015 \\
(0.60)\end{array}$ & $\begin{array}{l}0.026 \\
(0.99)\end{array}$ & $\begin{array}{l}0.121 \\
(3.52)\end{array}$ & $\begin{array}{l}0.111 \\
(3.03)\end{array}$ \\
\hline $\begin{array}{l}\text { Expect to Stay in } \\
\text { Australia }\end{array}$ & $\begin{array}{l}0.081 \\
(2.91)\end{array}$ & $\begin{array}{l}-0.103 \\
(2.57)\end{array}$ & $\begin{array}{l}-0.110 \\
(2.32)\end{array}$ & $\begin{array}{l}0.079 \\
(0.41)\end{array}$ & $\begin{array}{l}-0.073 \\
(1.21)\end{array}$ \\
\hline $\begin{array}{l}\text { Family Structure } \\
\text { MUS }^{(\mathrm{c})}\end{array}$ & $\begin{array}{l}-0.035 \\
(1.84)\end{array}$ & $\begin{array}{l}-0.004 \\
(0.13)\end{array}$ & $\begin{array}{l}-0.001 \\
(0.05)\end{array}$ & $\begin{array}{l}0.033 \\
(0.94)\end{array}$ & $\begin{array}{l}0.005 \\
(0.12)\end{array}$ \\
\hline $\operatorname{OS}^{(\mathrm{d})}$ & $\begin{array}{l}-0.014 \\
(0.64)\end{array}$ & $\begin{array}{l}0.014 \\
(0.45)\end{array}$ & $\begin{array}{l}0.036 \\
(1.19)\end{array}$ & $\begin{array}{l}0.071 \\
(1.56)\end{array}$ & $\begin{array}{l}0.013 \\
(0.21)\end{array}$ \\
\hline
\end{tabular}




\begin{tabular}{lccccc}
\hline KIDS $^{(\mathrm{e})}$ & -0.035 & -0.032 & -0.008 & -0.027 & -0.011 \\
& $(2.52)$ & $(1.62)$ & $(0.37)$ & $(1.08)$ & $(0.43)$ \\
MUR $^{(\mathrm{f})}$ & 0.016 & -0.069 & 0.054 & -0.067 & -0.069 \\
& $(0.53)$ & $(1.59)$ & $(1.27)$ & $(1.13)$ & $(1.16)$ \\
OR $^{(\mathrm{g})}$ & -0.093 & -0.044 & 0.032 & 0.026 & 0.045 \\
& $(2.78)$ & $(1.72)$ & $(0.87)$ & $(1.04)$ & $(2.18)$ \\
\multicolumn{1}{l}{ Birthplace (Europe and USSR) } & & & & \\
Oceania/Antarctica & 0.454 & -0.112 & -0.223 & -0.178 & -0.261 \\
& $(13.08)$ & $(2.19)$ & $(4.21)$ & $(2.95)$ & $(4.08)$ \\
Middle East and & 0.001 & 0.026 & 0.026 & -0.047 & 0.008 \\
North Africa & $(0.03)$ & $(0.86)$ & $(0.82)$ & $(1.23)$ & $(0.20)$ \\
Southeast Asia & 0.120 & -0.097 & -0.155 & -0.030 & -0.124 \\
& $(7.08)$ & $(3.88)$ & $(5.91)$ & $(0.88)$ & $(3.44)$ \\
Northeast Asia & -0.090 & -0.003 & -0.036 & -0.118 & -0.131 \\
& $(4.65)$ & $(0.10)$ & $(1.18)$ & $(3.29)$ & $(3.41)$ \\
Southern and Central & 0.213 & -0.028 & -0.099 & -0.067 & -0.147 \\
Asia & $(9.91)$ & $(0.88)$ & $(3.01)$ & $(1.72)$ & $(3.55)$ \\
South/Central & -0.093 & 0.009 & 0.051 & 0.057 & 0.074 \\
America and & $(2.33)$ & $(0.16)$ & $(0.81)$ & $(0.72)$ & $(0.89)$ \\
Caribbean & & & & & \\
Other Africa (Sub- & 0.242 & -0.026 & -0.112 & -0.085 & -0.135 \\
Saharan Africa) & $(6.99)$ & $(0.51)$ & $(2.08)$ & $(1.56)$ & $(2.38)$ \\
\hline For
\end{tabular}

For notes to Table, see Table 7. 
Table D.2

Ordered Probit Model Model of English Speaking Skills, 15-64 Year Old Males and Females from Non-English Speaking Countries

\begin{tabular}{|c|c|c|c|c|c|}
\hline \multirow[b]{2}{*}{ Variable $\left(X_{i}\right)$} & \multicolumn{3}{|c|}{ Cohort 1} & \multicolumn{2}{|c|}{ Cohort 2} \\
\hline & $\beta_{1} X_{i}$ & $\delta_{2} W 2_{i} X_{i}$ & $\delta_{3} W 3_{i} X_{i}$ & $\varphi_{1}{ }_{L S I A 2}{ }_{i} X_{i}$ & $\varphi_{2} \operatorname{LSIA2}_{i} W 2_{i} X_{i}$ \\
\hline $\begin{array}{l}\text { Constant/wave/cohort } \\
\text { effects }\end{array}$ & $\begin{array}{l}-0.664 \\
(4.31)\end{array}$ & $\begin{array}{l}1.117 \\
(5.01)\end{array}$ & $\begin{array}{l}1.639 \\
(6.73)\end{array}$ & $\begin{array}{l}0.873 \\
(1.39)\end{array}$ & $\begin{array}{l}1.222 \\
(3.75)\end{array}$ \\
\hline \multicolumn{6}{|c|}{ Visa Category (Independent) } \\
\hline $\begin{array}{l}\text { Humanitarian } \\
\text { (Refugee) }\end{array}$ & $\begin{array}{c}-0.823 \\
(11.84)\end{array}$ & $\begin{array}{l}0.280 \\
(2.77)\end{array}$ & $\begin{array}{l}0.363 \\
(3.43)\end{array}$ & $\begin{array}{l}-0.237 \\
(1.67)\end{array}$ & $\begin{array}{l}0.060 \\
(0.40)\end{array}$ \\
\hline Family & $\begin{array}{l}-0.422 \\
(5.27)\end{array}$ & $\begin{array}{l}0.089 \\
(0.80)\end{array}$ & $\begin{array}{l}0.093 \\
(0.84)\end{array}$ & $\begin{array}{l}-0.487 \\
(3.10)\end{array}$ & $\begin{array}{l}-0.336 \\
(2.23)\end{array}$ \\
\hline $\begin{array}{l}\text { Skilled-Australian } \\
\text { Sponsored }\end{array}$ & $\begin{array}{l}-0.127 \\
(1.70)\end{array}$ & $\begin{array}{l}0.007 \\
(0.07)\end{array}$ & $\begin{array}{l}0.070 \\
(0.62)\end{array}$ & $\begin{array}{l}0.088 \\
(0.69)\end{array}$ & $\begin{array}{l}0.159 \\
(1.15)\end{array}$ \\
\hline $\begin{array}{l}\text { Business } \\
\text { Skills/ENS }\end{array}$ & $\begin{array}{l}-0.363 \\
(3.32)\end{array}$ & $\begin{array}{l}0.126 \\
(0.78)\end{array}$ & $\begin{array}{l}0.121 \\
(0.72)\end{array}$ & $\begin{array}{l}-0.264 \\
(1.58)\end{array}$ & $\begin{array}{l}-0.204 \\
(1.12)\end{array}$ \\
\hline Age at Migration & $\begin{array}{l}-0.008 \\
(4.21)\end{array}$ & $\begin{array}{l}-0.006 \\
(2.18)\end{array}$ & $\begin{array}{l}-0.015 \\
(4.73)\end{array}$ & $\begin{array}{l}-0.009 \\
(2.34)\end{array}$ & $\begin{array}{l}-0.010 \\
(2.37)\end{array}$ \\
\hline Education & $\begin{array}{c}0.187 \\
(33.27)\end{array}$ & $\begin{array}{l}-0.029 \\
(3.54)\end{array}$ & $\begin{array}{l}-0.027 \\
(3.13)\end{array}$ & $\begin{array}{l}-0.041 \\
(4.03)\end{array}$ & $\begin{array}{l}-0.027 \\
(2.40)\end{array}$ \\
\hline Female & $\begin{array}{l}-0.205 \\
(5.49)\end{array}$ & $\begin{array}{l}0.095 \\
(1.73)\end{array}$ & $\begin{array}{l}0.087 \\
(1.50)\end{array}$ & $\begin{array}{l}0.222 \\
(3.22)\end{array}$ & $\begin{array}{l}0.246 \\
(3.38)\end{array}$ \\
\hline $\begin{array}{l}\text { Cross } \\
\text { Country/Culture } \\
\text { Contact in Former } \\
\text { Home Country }\end{array}$ & $\begin{array}{l}0.319 \\
(9.05)\end{array}$ & $\begin{array}{l}-0.078 \\
(1.50)\end{array}$ & $\begin{array}{l}-0.002 \\
(0.04)\end{array}$ & $\begin{array}{l}0.049 \\
(0.73)\end{array}$ & $\begin{array}{l}0.053 \\
(0.74)\end{array}$ \\
\hline $\begin{array}{l}\text { Previously Visited } \\
\text { Australia }\end{array}$ & $\begin{array}{l}0.759 \\
(7.55)\end{array}$ & $\begin{array}{l}-0.062 \\
(0.57)\end{array}$ & $\begin{array}{l}-0.205 \\
(1.84)\end{array}$ & $\begin{array}{l}0.072 \\
(0.99)\end{array}$ & $\begin{array}{l}-0.095 \\
(0.79)\end{array}$ \\
\hline $\begin{array}{l}\text { Main Reason for } \\
\text { Choosing State } \\
\text { Settled was } \\
\text { Family/Friends }\end{array}$ & $\begin{array}{l}-0.124 \\
(2.61)\end{array}$ & $\begin{array}{l}0.008 \\
(0.12)\end{array}$ & $\begin{array}{l}-0.030 \\
(0.41)\end{array}$ & $\begin{array}{l}0.005 \\
(0.06)\end{array}$ & $\begin{array}{l}-0.013 \\
(0.15)\end{array}$ \\
\hline $\begin{array}{l}\text { Contact with Ethnic } \\
\text { Agencies }\end{array}$ & $\begin{array}{l}-0.203 \\
(3.95)\end{array}$ & $\begin{array}{l}0.086 \\
(1.17)\end{array}$ & $\begin{array}{l}0.136 \\
(1.79)\end{array}$ & $\begin{array}{l}0.243 \\
(2.38)\end{array}$ & $\begin{array}{l}0.262 \\
(2.39)\end{array}$ \\
\hline $\begin{array}{l}\text { Expect to Stay in } \\
\text { Australia }\end{array}$ & $\begin{array}{l}0.280 \\
(3.42)\end{array}$ & $\begin{array}{l}-0.210 \\
(1.78)\end{array}$ & $\begin{array}{l}0.302 \\
(2.19)\end{array}$ & $\begin{array}{l}0.072 \\
(0.13)\end{array}$ & $\begin{array}{l}-0.082 \\
(0.46)\end{array}$ \\
\hline $\begin{array}{l}\text { Family Structure } \\
\text { MUS }^{(\mathrm{c})}\end{array}$ & $\begin{array}{l}-0.134 \\
(2.34)\end{array}$ & $\begin{array}{l}0.099 \\
(1.18)\end{array}$ & $\begin{array}{l}0.086 \\
(0.95)\end{array}$ & $\begin{array}{l}0.123 \\
(1.17)\end{array}$ & $\begin{array}{l}0.155 \\
(1.33)\end{array}$ \\
\hline $\operatorname{OS}^{(\mathrm{d})}$ & $\begin{array}{l}-0.107 \\
(1.61)\end{array}$ & $\begin{array}{l}0.136 \\
(1.49)\end{array}$ & $\begin{array}{l}0.220 \\
(2.44)\end{array}$ & $\begin{array}{l}0.322 \\
(2.32)\end{array}$ & $\begin{array}{l}0.030 \\
(0.16)\end{array}$ \\
\hline $\operatorname{KIDS}^{(\mathrm{e})}$ & $\begin{array}{l}-0.160 \\
(3.82)\end{array}$ & $\begin{array}{l}-0.023 \\
(0.39)\end{array}$ & $\begin{array}{l}-0.031 \\
(0.49)\end{array}$ & $\begin{array}{l}0.058 \\
(0.77)\end{array}$ & $\begin{array}{l}0.002 \\
(0.02)\end{array}$ \\
\hline $\operatorname{MUR}^{(\mathrm{f})}$ & $\begin{array}{l}0.124 \\
(1.34)\end{array}$ & $\begin{array}{l}-0.110 \\
(0.86)\end{array}$ & $\begin{array}{l}0.245 \\
(1.95)\end{array}$ & $\begin{array}{l}-0.442 \\
(2.46)\end{array}$ & $\begin{array}{l}-0.241 \\
(1.37)\end{array}$ \\
\hline
\end{tabular}




\begin{tabular}{lccccc}
\hline OR $^{(\mathrm{g})}$ & -0.314 & 0.016 & -0.046 & 0.087 & 0.077 \\
& $(3.15)$ & $(0.21)$ & $(0.41)$ & $(1.18)$ & $(1.25)$ \\
\multicolumn{2}{l}{ Birthplace (Europe and USSR) } & & & & \\
Oceania/Antarctica & 2.081 & -0.422 & -0.722 & -0.626 & -0.292 \\
& $(19.52)$ & $(2.66)$ & $(4.42)$ & $(3.37)$ & $(1.39)$ \\
& 0.060 & 0.011 & 0.040 & -0.062 & 0.083 \\
Middle East and & $(0.97)$ & $(0.12)$ & $(0.43)$ & $(0.54)$ & $(0.69)$ \\
North Africa & & & & & \\
& 0.545 & -0.213 & -0.410 & -0.089 & -0.190 \\
Southeast Asia & $(10.83)$ & $(2.89)$ & $(5.33)$ & $(0.90)$ & $(1.80)$ \\
& -0.423 & -0.065 & -0.124 & -0.313 & -0.400 \\
Northeast Asia & $(7.44)$ & $(0.78)$ & $(1.38)$ & $(2.97)$ & $(3.57)$ \\
& 1.147 & -0.211 & -0.363 & -0.145 & -0.169 \\
Southern and Central & $(18.11)$ & $(2.28)$ & $(3.77)$ & $(1.25)$ & $(1.36)$ \\
Asia & -0.272 & -0.026 & 0.214 & 0.203 & 0.142 \\
South/Central & $(2.31)$ & $(0.15)$ & $(1.16)$ & $(0.87)$ & $(0.59)$ \\
America and & & & & & \\
Caribbean & 1.271 & -0.195 & -0.226 & 0.138 & -0.071 \\
Other Africa (Sub- & $(12.02)$ & $(1.25)$ & $(1.36)$ & $(0.81)$ & $(0.40)$ \\
Saharan Africa) & & & &
\end{tabular}

For notes to Table, see Table 7. 


\section{APPENDIX E}

Table E.1

Linear Probability (OLS) Model of English Speaking Skills, 15-64 Year Old Males and Females from Non-English Speaking Countries, With and Without Individual Fixed Effects

\begin{tabular}{|c|c|c|c|c|c|}
\hline \multirow[b]{2}{*}{ Variable $\left(X_{i}\right)$} & \multicolumn{3}{|c|}{ Cohort 1} & \multicolumn{2}{|c|}{ Cohort 2} \\
\hline & $\beta_{1} X_{i}$ & $\delta_{2} W 2_{i} X_{i}$ & $\delta_{3} W 3_{i} X_{i}$ & $\varphi_{1}{ }_{L S I A 2}{ }_{i} X_{i}$ & $\varphi_{2} \operatorname{LSIA2}_{i} W 2_{i} X_{i}$ \\
\hline \multicolumn{6}{|l|}{ Without Fixed Effects } \\
\hline $\begin{array}{l}\text { Constant/wave/cohort } \\
\text { effects }\end{array}$ & $\begin{array}{r}-0.060 \\
(1.16)\end{array}$ & $\begin{array}{l}0.269 \\
(3.55)\end{array}$ & $\begin{array}{l}0.392 \\
(4.73)\end{array}$ & $\begin{array}{l}0.180 \\
(0.85)\end{array}$ & $\begin{array}{l}0.349 \\
(3.19)\end{array}$ \\
\hline \multicolumn{6}{|c|}{ Visa Category (Independent) } \\
\hline $\begin{array}{l}\text { Humanitarian } \\
\text { (Refugee) }\end{array}$ & $\begin{array}{l}-0.359 \\
(15.29)\end{array}$ & $\begin{array}{l}0.185 \\
(5.39)\end{array}$ & $\begin{array}{l}0.261 \\
(7.22)\end{array}$ & $\begin{array}{l}0.013 \\
(0.27)\end{array}$ & $\begin{array}{l}0.127 \\
(2.50)\end{array}$ \\
\hline Family & $\begin{array}{l}-0.205 \\
(7.62)\end{array}$ & $\begin{array}{l}0.080 \\
(2.12)\end{array}$ & $\begin{array}{l}0.125 \\
(3.32)\end{array}$ & $\begin{array}{l}-0.084 \\
(1.62)\end{array}$ & $\begin{array}{l}0.015 \\
(0.30)\end{array}$ \\
\hline $\begin{array}{l}\text { Skilled-Australian } \\
\text { Sponsored }\end{array}$ & $\begin{array}{r}-0.117 \\
(4.61)\end{array}$ & $\begin{array}{l}0.063 \\
(1.72)\end{array}$ & $\begin{array}{l}0.111 \\
(2.89)\end{array}$ & $\begin{array}{l}0.102 \\
(2.40)\end{array}$ & $\begin{array}{l}0.126 \\
(2.83)\end{array}$ \\
\hline $\begin{array}{l}\text { Business } \\
\text { Skills/ENS }\end{array}$ & $\begin{array}{l}-0.206 \\
(5.54)\end{array}$ & $\begin{array}{l}0.063 \\
(1.15)\end{array}$ & $\begin{array}{l}0.093 \\
(1.61)\end{array}$ & $\begin{array}{l}0.032 \\
(0.56)\end{array}$ & $\begin{array}{l}0.100 \\
(1.64)\end{array}$ \\
\hline Age at Migration & $\begin{array}{r}-0.001 \\
(2.21)\end{array}$ & $\begin{array}{l}-0.004 \\
(3.57)\end{array}$ & $\begin{array}{l}-0.007 \\
(7.13)\end{array}$ & $\begin{array}{l}-0.004 \\
(2.89)\end{array}$ & $\begin{array}{l}-0.006 \\
(4.17)\end{array}$ \\
\hline Education & $\begin{array}{c}0.050 \\
(26.96)\end{array}$ & $\begin{array}{l}0.002 \\
(0.64)\end{array}$ & $\begin{array}{l}0.005 \\
(1.90)\end{array}$ & $\begin{array}{l}-0.011 \\
(3.10)\end{array}$ & $\begin{array}{l}-0.002 \\
(0.55)\end{array}$ \\
\hline \multicolumn{6}{|l|}{$\underline{\text { With Fixed Effects }}$} \\
\hline Constant & - & $\begin{array}{l}0.168 \\
(2.86)\end{array}$ & $\begin{array}{l}0.331 \\
(5.09)\end{array}$ & - & $\begin{array}{l}0.022 \\
(0.11)\end{array}$ \\
\hline \multicolumn{6}{|c|}{ Visa Category (Independent) } \\
\hline $\begin{array}{l}\text { Humanitarian } \\
\text { (Refugee) }\end{array}$ & - & $\begin{array}{l}0.133 \\
(5.42)\end{array}$ & $\begin{array}{l}0.229 \\
(8.75)\end{array}$ & - & $\begin{array}{l}0.181 \\
(4.69)\end{array}$ \\
\hline Preferential Family & - & $\begin{array}{l}0.058 \\
(1.95)\end{array}$ & $\begin{array}{l}0.111 \\
(3.51)\end{array}$ & - & $\begin{array}{l}0.113 \\
(2.86)\end{array}$ \\
\hline $\begin{array}{l}\text { Skilled-Australian } \\
\text { Sponsored }\end{array}$ & - & $\begin{array}{l}0.042 \\
(1.81)\end{array}$ & $\begin{array}{l}0.114 \\
(4.68)\end{array}$ & - & $\begin{array}{l}0.023 \\
(0.63)\end{array}$ \\
\hline $\begin{array}{l}\text { Business } \\
\text { Skills/ENS }\end{array}$ & - & $\begin{array}{l}0.054 \\
(1.91)\end{array}$ & $\begin{array}{l}0.108 \\
(3.54)\end{array}$ & - & $\begin{array}{l}0.070 \\
(1.77)\end{array}$ \\
\hline Age at Migration & - & $\begin{array}{l}-0.004 \\
(5.22)\end{array}$ & $\begin{array}{l}-0.008 \\
(9.20)\end{array}$ & - & $\begin{array}{l}-0.003 \\
(2.85)\end{array}$ \\
\hline Education & $\begin{array}{r}-0.010 \\
(0.98)\end{array}$ & $\begin{array}{l}0.002 \\
(1.15)\end{array}$ & $\begin{array}{l}0.001 \\
(0.51)\end{array}$ & $\begin{array}{l}0.048 \\
(2.09)\end{array}$ & $\begin{array}{l}0.050 \\
(2.15)\end{array}$ \\
\hline
\end{tabular}

Note: - indicates effect captured as a fixed effect as the variable does not change across waves of data collection for the particular cohort of immigrants. 


\section{APPENDIX F \\ MIGRATING UNIT SPOUSES: ANALYSES}

Table F.1

Models of English Speaking Skills, 15 - 64 Year Old Males and Females from NonEnglish Speaking Countries

\begin{tabular}{|c|c|c|c|}
\hline Variable & $\begin{array}{l}\text { OLS } \\
\text { (i) }\end{array}$ & $\begin{array}{l}\text { Probit } \\
\text { (ii) }\end{array}$ & $\begin{array}{l}\text { Ordered Probit } \\
\text { (iii) }\end{array}$ \\
\hline Constant & $\begin{array}{l}0.282 \\
(4.52)\end{array}$ & $\begin{array}{l}-0.724 \\
(3.45)\end{array}$ & $\begin{array}{l}0.682 \\
(4.34)\end{array}$ \\
\hline $\begin{array}{l}\text { Visa Category (Independent) } \\
\text { Humanitarian (Refugee) }\end{array}$ & $\begin{array}{l}-0.244 \\
(11.17)\end{array}$ & $\begin{array}{l}-0.714 \\
(10.12)\end{array}$ & $\begin{array}{l}-0.629 \\
(11.67)\end{array}$ \\
\hline Family & $\begin{array}{l}-0.195 \\
(5.76)\end{array}$ & $\begin{array}{r}-0.679 \\
(5.39)\end{array}$ & $\begin{array}{l}-0.923 \\
(9.82)\end{array}$ \\
\hline Skilled-Australian Sponsored & $\begin{array}{l}0.006 \\
(0.35)\end{array}$ & $\begin{array}{l}0.043 \\
(0.63)\end{array}$ & $\begin{array}{l}0.007 \\
(0.14)\end{array}$ \\
\hline Business Skills/ENS ${ }^{(b)}$ & $\begin{array}{l}-0.070 \\
(2.71)\end{array}$ & $\begin{array}{l}-0.240 \\
(2.69)\end{array}$ & $\begin{array}{l}-0.181 \\
(2.70)\end{array}$ \\
\hline Age at Migration & $\begin{array}{l}-0.006 \\
(7.04)\end{array}$ & $\begin{array}{l}-0.023 \\
(7.27)\end{array}$ & $\begin{array}{l}-0.014 \\
(6.27)\end{array}$ \\
\hline Education & $\begin{array}{c}0.034 \\
(15.37)\end{array}$ & $\begin{array}{c}0.116 \\
(18.15)\end{array}$ & $\begin{array}{c}0.093 \\
(19.05)\end{array}$ \\
\hline Female & $\begin{array}{l}-0.108 \\
(7.44)\end{array}$ & $\begin{array}{l}-0.444 \\
(7.82)\end{array}$ & $\begin{array}{l}-0.347 \\
(8.53)\end{array}$ \\
\hline $\begin{array}{l}\text { Cross Country/Culture Contact in } \\
\text { Former Home Country }\end{array}$ & $\begin{array}{l}0.106 \\
(8.66)\end{array}$ & $\begin{array}{l}0.379 \\
(8.55)\end{array}$ & $\begin{array}{l}0.321 \\
(9.73)\end{array}$ \\
\hline Previously Visited Australia & $\begin{array}{l}0.116 \\
(8.17)\end{array}$ & $\begin{array}{l}0.479 \\
(8.14)\end{array}$ & $\begin{array}{c}0.522 \\
(12.59)\end{array}$ \\
\hline $\begin{array}{l}\text { Main Reason for Choosing State } \\
\text { Settled was Family/Friends }\end{array}$ & $\begin{array}{l}-0.060 \\
(4.49)\end{array}$ & $\begin{array}{r}-0.242 \\
(4.91)\end{array}$ & $\begin{array}{l}-0.119 \\
(3.29)\end{array}$ \\
\hline Contact with Ethnic Agencies & $\begin{array}{l}-0.018 \\
(1.23)\end{array}$ & $\begin{array}{c}-0.057 \\
(1.03)\end{array}$ & $\begin{array}{l}-0.066 \\
(1.61)\end{array}$ \\
\hline Expect to Stay in Australia & $\begin{array}{l}0.098 \\
(3.37)\end{array}$ & $\begin{array}{l}0.383 \\
(3.26)\end{array}$ & $\begin{array}{l}0.407 \\
(4.74)\end{array}$ \\
\hline $\operatorname{KIDS}^{(\mathrm{c})}$ & $\begin{array}{l}-0.111 \\
(7.72)\end{array}$ & $\begin{array}{r}-0.407 \\
(6.81)\end{array}$ & $\begin{array}{l}-0.284 \\
(6.73)\end{array}$ \\
\hline MURS $^{(\mathrm{d})}$ & $\begin{array}{l}0.015 \\
(0.68)\end{array}$ & $\begin{array}{l}0.030 \\
(0.35)\end{array}$ & $\begin{array}{c}0.075 \\
(1.19)\end{array}$ \\
\hline $\mathrm{OR}^{(\mathrm{e})}$ & $\begin{array}{l}-0.006 \\
(0.35)\end{array}$ & $\begin{array}{r}-0.027 \\
(0.41)\end{array}$ & $\begin{array}{l}-0.059 \\
(1.22)\end{array}$ \\
\hline Weeks in Australia/100 & $\begin{array}{c}0.147 \\
(15.90)\end{array}$ & $\begin{array}{c}0.542 \\
(14.65)\end{array}$ & $\begin{array}{c}0.362 \\
(13.81)\end{array}$ \\
\hline \multicolumn{4}{|l|}{ Birthplace (Europe and USSR) } \\
\hline Oceania/Antarctica & 0.294 & 1.466 & 1.237 \\
\hline
\end{tabular}




\begin{tabular}{lccc}
\hline & $(10.39)$ & $(7.52)$ & $(11.30)$ \\
Middle East and North Africa & 0.063 & 0.216 & 0.150 \\
& $(2.86)$ & $(2.86)$ & $(2.62)$ \\
Southeast Asia & 0.092 & 0.339 & 0.257 \\
& $(4.84)$ & $(4.54)$ & $(4.74)$ \\
Northeast Asia & -0.129 & -0.426 & -0.482 \\
& $(5.99)$ & $(5.74)$ & $(8.64)$ \\
Southern and Central Asia & 0.140 & 0.549 & 0.776 \\
& $(7.17)$ & $(7.61)$ & $(14.64)$ \\
South/Central America and & -0.027 & -0.079 & -0.158 \\
Caribbean & $(0.63)$ & $(0.51)$ & $(1.36)$ \\
Other Africa (Sub-Saharan Africa) & 0.209 & 0.731 & 1.112 \\
& $(6.13)$ & $(4.65)$ & $(9.83)$ \\
$\mu_{1}$ & (a) & (a) & 1.550 \\
$\mu_{2}$ & & & $(68.41)$ \\
$\mu_{3}$ & (a) & (a) & 2.632 \\
$\chi^{2}$ & & & $(120.52)$ \\
Prediction Success Rate (\%) & (a) & (a) & 3.094 \\
Adjusted $R^{2}$ & & & $(122.87)$ \\
F - test & (a) & 2080.13 & 2484.63 \\
Sample Size & (a) & 75.92 & 48.63 \\
\hline
\end{tabular}

Notes: Numbers in parentheses are ' $t$ ' statistics; No statistical control for cohort, and with a duration of residence variable (weeks in Australia) in place of wave dummy variables.

(a) Variable not relevant.

(b) ENS denotes Employer Nomination Scheme.

(c) Whether there are children in the household.

(d) Whether other relatives who gained approval to migrate to Australia as part of the Principal Applicant's migration application are present in the household.

(e) Whether other relatives are present in the household.

Source: Longitudinal Survey of Immigrants to Australia, Cohorts I and II.

The table above presents the estimates for the OLS model, the Probit model and the Ordered Probit model. The structure of this table is the same as that of Table 7. However, the data used in these models are based on the information of the spouses (only of those who are present with available data) of the primary applicants who were part of the initial application to migrate to Australia. In other words, if an individual migrated to Australia to join a spouse who was already a resident of Australia, or if they married after arrival in Australia, then that spouse is not included in the analysis. 
The dependent variable in the first two models is the binary measure of English proficiency, while all of the categories of English skills presented in the data are used in the third model.

The estimates for the four different visa classes (Humanitarian Visa, Family Visa, Skilled-Australian Sponsored Visa, and Business Skills/ENS Visa) show the effects of membership of the particular visa classes compared with the benchmark group of those who entered Australia on an Independent Visa. All these estimates are negative, indicating that spouses who entered Australia under these types of visas have lower English speaking skills as compared to those with Independent visas. It is worth noting that the ranking of coefficients (Independent Visa, Skill-Australian Sponsored, Business Skills/ENS Visa, Family Visa, Humanitarian Visa) is consistent across the OLS model and the Probit model. ${ }^{33}$ This is the same ranking as was established for the Principal Applicants, though in the case of that analysis the coefficient for the Skilled-Australian Sponsored immigrants was statistically significant. This similarity presumably comes about through assortive mating and the complementarities of the post-migration learning of English among family members that has been emphasised by Chiswick, Lee and Miller (2004b).

The variable for age at migration is found to have a negative impact on English proficiency. The OLS results in column (i) shows that the level of English speaking skills decreases by 0.6 percentage points with each additional year of age at migration. The Probit result offer a similar insight into the effect of age at migration on English learning skills. The estimated age effect on English proficiency among the Migrating Unit Spouses is remarkably similar to that for Principal Applicants. As age at migration is often argued to represent efficiency in language production, this type of result might be expected.

Immigrants' English speaking skills have a strong positive relationship with educational attainment. According to the OLS analysis, each additional year of schooling increases English speaking proficiency by 3 percentage points. This implies that

\footnotetext{
${ }^{33}$ The coefficients for the Skilled-Australian Sponsored visa are statistically insignificant across all models.
} 
education level has a similar impact on the English speaking skills of both the primary applicants and their spouses, though the impact is smaller (by about 50 percent) for the latter.

The female spouses of the primary applicants have lower English proficiency as compared to the male spouses. The estimated coefficient in the OLS model indicates a 11 percentage points gender differential in English speaking skills. This illustrates a greater gender effect as compared to the 3 percentage point gender differential among the primary applicants.

Those spouses who have had "cross country/culture contact in the former home country" and who "previously visited Australia" have higher English proficiency than those who do not have these characteristics. Exposure to Australia before migration apparently speeds up the rate of language learning and adaptability.

The presence of family and friends being the main reason for the location decision within Australia is found to have a negative impact on English speaking skills. In this situation, immigrants will presumably have less incentive and opportunity to speak English if they are able to communicate in their mother tongue for most of the time. This argument also appears to hold for those who have contact with ethnic agencies after arrival in Australia. However, the estimated coefficients for this variable are insignificant for all models.

The variable capturing the expectation of staying in Australia has a positive impact on the English language skills of the primary applicants' spouses. Moreover, it is noted that this variable has a greater impact on the English speaking skills of the spouses than on that of the primary applicants.

The variable that represents the weeks of residence in Australia for the spouses has a significant positive impact on their English speaking skills. The OLS analysis records an improvement on proficiency level of 15 percentage points per 100 weeks in Australia. This rate of improvement surpasses that of the primary applicants, which was 9 percentage points. This may simply be an "initial conditions" effect, whereby the migrating unit spouses have more limited English skills at the time of migration and hence greater opportunity for advancement in their English skills. 
Three different variables are used to capture the effects of the family composition of the immigrants' household on the spouses' English speaking skills. The variable that records the presence of children in the household has a negative impact on English proficiency. ${ }^{34}$ The presence of children in the family has a greater impact on the spouses' English speaking skills than on the skills of the primary applicants. The OLS estimates show that the English proficiency for spouses decreases by 11 percentage points, compared to 4 percentage points for the primary applicants, if children are present in the household.

There are seven birthplace dummy variables included in the model namely, 'Oceania/Antarctica', 'Middle East and North Africa', 'Southeast Asia', 'Northeast Asia', 'Southern and Central Asia', 'South/Central America and Caribbean', and 'Other Africa (Sub-Saharan Africa)'. The birthplace group of Europe and the USSR is the benchmark group for these dummy variables. Each of the dummies shows a positive impact on English speaking skills except for the 'Northeast Asia'. ${ }^{35}$ The positive coefficients indicate that spouses who were born in these birthplace groups have higher English speaking skills than those who are born in Europe and the USSR. As for those spouses who are born in Northeast Asia, they will have lower English proficiency level compared to those born in Europe and the USSR.

\footnotetext{
${ }^{34}$ Among the three variables that record the household composition, this is the only variable (KIDS) that is statistically significant.

35 The birthplace group of 'South/Central America and Caribbean' is statistically insignificant across all estimating models.
} 
Table F.2

Probit Model of English Speaking Skills, 15-64 Year Old Males and Females from Non-English Speaking Countries

\begin{tabular}{|c|c|c|c|c|c|}
\hline \multirow[b]{2}{*}{ Variable $\left(X_{i}\right)$} & \multicolumn{3}{|c|}{ Cohort 1} & \multicolumn{2}{|c|}{ Cohort 2} \\
\hline & $\beta_{1} X_{i}$ & $\delta_{2} W 2_{i} X_{i}$ & $\delta_{3} W 3_{i} X_{i}$ & $\varphi_{1}{ }_{L S I A 2}{ }_{i} X_{i}$ & $\varphi_{2}{ }^{L S I A 2}{ }_{i} W 2_{i} X_{i}$ \\
\hline $\begin{array}{l}\text { Constant/wave/cohort } \\
\text { effects }\end{array}$ & $\begin{array}{l}-2.383 \\
(5.85)\end{array}$ & $\begin{array}{l}1.158 \\
(1.96)\end{array}$ & $\begin{array}{l}2.462 \\
(3.75)\end{array}$ & $\begin{array}{l}4.920 \\
(2.22)\end{array}$ & $\begin{array}{l}2.540 \\
(2.67)\end{array}$ \\
\hline \multicolumn{6}{|c|}{ Visa Category (Independent) } \\
\hline $\begin{array}{l}\text { Humanitarian } \\
\text { (Refugee) }\end{array}$ & $\begin{array}{l}-0.734 \\
(5.53)\end{array}$ & $\begin{array}{l}0.108 \\
(0.56)\end{array}$ & $\begin{array}{l}0.147 \\
(0.68)\end{array}$ & $\begin{array}{l}-0.307 \\
(1.16)\end{array}$ & $\begin{array}{l}-0.230 \\
(0.70)\end{array}$ \\
\hline Family & $\begin{array}{l}-0.508 \\
(2.13)\end{array}$ & $\begin{array}{l}-0.088 \\
(0.25)\end{array}$ & $\begin{array}{l}0.482 \\
(1.33)\end{array}$ & $\begin{array}{l}-1.499 \\
(2.18)\end{array}$ & $\begin{array}{l}-0.725 \\
(1.21)\end{array}$ \\
\hline $\begin{array}{l}\text { Skilled-Australian } \\
\text { Sponsored }\end{array}$ & $\begin{array}{l}0.014 \\
(0.11)\end{array}$ & $\begin{array}{l}0.093 \\
(0.50)\end{array}$ & $\begin{array}{l}-0.222 \\
(1.04)\end{array}$ & $\begin{array}{l}0.273 \\
(1.18)\end{array}$ & $\begin{array}{l}0.669 \\
(2.23)\end{array}$ \\
\hline $\begin{array}{l}\text { Business } \\
\text { Skills/ENS }\end{array}$ & $\begin{array}{l}-0.406 \\
(2.33)\end{array}$ & $\begin{array}{l}0.351 \\
(1.34)\end{array}$ & $\begin{array}{l}0.193 \\
(0.66)\end{array}$ & $\begin{array}{l}0.187 \\
(0.66)\end{array}$ & $\begin{array}{l}0.225 \\
(0.68)\end{array}$ \\
\hline Education & $\begin{array}{c}0.162 \\
(11.10)\end{array}$ & $\begin{array}{l}0.005 \\
(0.26)\end{array}$ & $\begin{array}{l}0.044 \\
(1.94)\end{array}$ & $\begin{array}{l}-0.159 \\
(7.65)\end{array}$ & $\begin{array}{l}-0.022 \\
(0.71)\end{array}$ \\
\hline Age at Migration & $\begin{array}{r}-0.006 \\
(1.00)\end{array}$ & $\begin{array}{l}-0.015 \\
(1.72)\end{array}$ & $\begin{array}{l}-0.040 \\
(4.13)\end{array}$ & $\begin{array}{l}-0.027 \\
(2.29)\end{array}$ & $\begin{array}{l}-0.042 \\
(3.16)\end{array}$ \\
\hline Female & $\begin{array}{r}-0.122 \\
(1.10)\end{array}$ & $\begin{array}{l}-0.298 \\
(1.85)\end{array}$ & $\begin{array}{l}-0.329 \\
(1.88)\end{array}$ & $\begin{array}{l}-0.896 \\
(4.44)\end{array}$ & $\begin{array}{l}-0.401 \\
(1.75)\end{array}$ \\
\hline $\operatorname{KIDS}^{(\mathrm{c})}$ & $\begin{array}{l}-0.241 \\
(2.34)\end{array}$ & $\begin{array}{l}-0.137 \\
(0.83)\end{array}$ & $\begin{array}{l}-0.559 \\
(2.76)\end{array}$ & $\begin{array}{l}-0.786 \\
(3.76)\end{array}$ & $\begin{array}{l}-0.220 \\
(0.86)\end{array}$ \\
\hline $\operatorname{MUR}^{(\mathrm{d})}$ & $\begin{array}{l}0.338 \\
(1.96)\end{array}$ & $\begin{array}{l}-0.133 \\
(0.56)\end{array}$ & $\begin{array}{l}-0.345 \\
(1.46)\end{array}$ & $\begin{array}{l}-0.856 \\
(2.29)\end{array}$ & $\begin{array}{l}-0.387 \\
(1.13)\end{array}$ \\
\hline $\mathrm{OR}^{(\mathrm{e})}$ & $\begin{array}{l}-0.301 \\
(0.95)\end{array}$ & $\begin{array}{l}0.310 \\
(1.25)\end{array}$ & $\begin{array}{l}0.161 \\
(0.46)\end{array}$ & $\begin{array}{l}0.246 \\
(1.05)\end{array}$ & $\begin{array}{l}0.026 \\
(0.13)\end{array}$ \\
\hline $\begin{array}{l}\text { Previously Visited } \\
\text { Australia }\end{array}$ & $\begin{array}{l}-0.062 \\
(0.22)\end{array}$ & $\begin{array}{l}0.324 \\
(1.06)\end{array}$ & $\begin{array}{l}0.415 \\
(1.32)\end{array}$ & $\begin{array}{l}0.412 \\
(2.01)\end{array}$ & $\begin{array}{l}0.674 \\
(1.84)\end{array}$ \\
\hline $\begin{array}{l}\text { Expect to Stay in } \\
\text { Australia }\end{array}$ & $\begin{array}{l}0.027 \\
(0.13)\end{array}$ & $\begin{array}{l}0.396 \\
(1.33)\end{array}$ & $\begin{array}{l}0.372 \\
(1.10)\end{array}$ & $\begin{array}{l}0.455 \\
(0.22)\end{array}$ & $\begin{array}{l}1.569 \\
(3.29)\end{array}$ \\
\hline $\begin{array}{l}\text { Cross } \\
\text { Country/Culture } \\
\text { Contact in Former } \\
\text { Home Country }\end{array}$ & $\begin{array}{l}0.612 \\
(7.10)\end{array}$ & $\begin{array}{l}-0.120 \\
(0.97)\end{array}$ & $\begin{array}{l}-0.112 \\
(0.83)\end{array}$ & $\begin{array}{l}-0.426 \\
(2.67)\end{array}$ & $\begin{array}{l}-0.335 \\
(1.86)\end{array}$ \\
\hline $\begin{array}{l}\text { Main Reason for } \\
\text { Choosing State } \\
\text { Settled was } \\
\text { Family/Friends }\end{array}$ & $\begin{array}{r}-0.148 \\
(1.58)\end{array}$ & $\begin{array}{l}-0.054 \\
(0.40)\end{array}$ & $\begin{array}{l}0.007 \\
(0.04)\end{array}$ & $\begin{array}{l}-0.269 \\
(1.61)\end{array}$ & $\begin{array}{l}-0.098 \\
(0.50)\end{array}$ \\
\hline $\begin{array}{l}\text { Contact with Ethnic } \\
\text { Agencies }\end{array}$ & $\begin{array}{l}-0.295 \\
(2.73)\end{array}$ & $\begin{array}{l}0.289 \\
(1.89)\end{array}$ & $\begin{array}{l}0.374 \\
(2.20)\end{array}$ & $\begin{array}{l}0.274 \\
(1.35)\end{array}$ & $\begin{array}{l}0.305 \\
(1.36)\end{array}$ \\
\hline
\end{tabular}




\begin{tabular}{llllll}
\hline \multicolumn{2}{l}{ Birthplace (Europe and USSR) } & & & & \\
Oceania/Antarctica & 2.056 & -0.548 & -0.387 & -0.682 & - \\
& $(5.49)$ & $(0.98)$ & $(0.67)$ & $(1.10)$ & \\
Middle East and & 0.433 & -0.036 & -0.321 & -0.736 & -0.753 \\
North Africa & $(2.86)$ & $(0.17)$ & $(1.44)$ & $(2.49)$ & $(2.44)$ \\
Southeast Asia & 0.681 & -0.388 & -0.551 & -0.238 & -1.248 \\
& $(4.77)$ & $(1.87)$ & $(2.54)$ & $(0.80)$ & $(3.35)$ \\
Northeast Asia & 0.106 & -0.454 & -0.546 & -1.150 & -1.735 \\
& $(0.78)$ & $(2.26)$ & $(2.42)$ & $(4.16)$ & $(4.85)$ \\
Southern and & 0.939 & -0.356 & -0.430 & -0.600 & -1.283 \\
Central Asia & $(7.17)$ & $(1.81)$ & $(1.89)$ & $(2.34)$ & $(3.84)$ \\
South/Central & 0.076 & -0.211 & 0.205 & -0.903 & -1.097 \\
America and & $(0.27)$ & $(0.52)$ & $(0.45)$ & $(1.33)$ & $(1.37)$ \\
Caribbean & & & & & \\
Other Africa (Sub- & 1.045 & 0.001 & -0.530 & 0.230 & -1.713 \\
Saharan Africa) & $(3.06)$ & $(0.00)$ & $(0.95)$ & $(0.46)$ & $(3.32)$ \\
\hline
\end{tabular}

For notes to Table, see Table 7.

The structure of this table is that same as Table 9, though the focus of analysis is based on the spouses of the primary applicants rather than on primary applicants themselves.

It is evidenced from the table above that English language proficiency increase with duration of residence of Australia, as indicated by the positive sign of estimated coefficients on the wave shift factors (listed in the row for the constant term). The pattern portrayed in this table is consistent with those in Table 9: It is found that most of the language skill improvement appears to occur over the initial settlement period, with the difference between wave 3 and wave 2 being statistically insignificant. The magnitude of this effect, however, exceed that in Table 9.

It is also noted that spouses of second cohort's immigrants have greater English speaking skills as compared to the spouses of first cohort's. Even though the coefficient on the wave shift factor for the second cohort wave 2 falls short of that for second cohort wave 1 , the difference between these two waves are statistically insignificant. 